\title{
Timo Leisiö
}

\section{MELODIAN SYNTAKSI KOLMESSA JAAVALAISESSA LASTENLAULUSSA JA EKSKURSIO KAAKKOISAASIALAISEN LAULUN MENNEISYYTEEN}

Jaava on liki tuhannen kilometrin pituinen saari Indonesiassa hieman päiväntasaajan eteläpuolella. Saari on tiheään asuttu: melkein kaksi kolmesta indonesialaisesta elää Jaavalla, jolla ihminen on viihtynyt tuhannet vuodet. Jaavan kieli kuuluu austronesialaisten kielten malajo-polynesialaiseen länsiryhmään ja tarkemmin sen sundalaiseen alaperheeseen, jota puhutaan Balilla, Jaavalla, Sumatralla, Malesiassa sekä paikoin myös Thaimaan, Kamputsean, Vietnamin ja Kiinan eteläosissa. Artikkelin alunalkuisena päämääränä oli kokeilla, miten tutkasävelteoria toimii, jos sen avulla koettaa määrittää jaavalaisen laulun varsin erikoislaatuista ja eurooppalaiselle vaikeaselkoista logiikkaa eli melodianmuodostuksen pohjana olevia sääntöjä. Teoriasta johtuva menetelmä toimii, mutta tulokset yllättivät kirjoittajan ja johtivat aivan ennakoimattomaan suuntaan eli miettimään melodianmuodostuksen erikoispiirteiden menneisyyttä laajalla maantieteellisellä alueella ja varsin laajassa aikaperspektiivissä. Keskeisenä tehtävänä on pyrkiä ymmärtämään syntaksien rakentumisen periaatteita sekä sitä, miksi melodianmuodostus Jaavalla on toisenlaista kuin Afrikassa ja Euroopassa.

Jaavalaisen laulun erikoistuntija on Margaret Kartomi, australialaisen Monashin yliopiston musiikkitieteen professori. Hänen väitöskirjansa kohteena oli laululaji nimeltään macapat (aiempi kirjoitusasu oli matjapat), ja tutkimus julkaistiin vuonna 1973. Macapatilla on hieman sama merkitys Jaavalla kuin runosävelmillä itämerensuomalaisille, paitsi että traditio kuuluu edelleen normaaliarkeen. Sen melodiat ovat länsimaalaiselle vaikeita hahmottaa ja muistaa. Lasten laulamat sävelmät ovat 
paikallisten syntaksien kiteytymiä, eivät yhtä monimutkaisia kuin aikuisten laulut saattavat olla. Tämän oletuksen vuoksi pyysin Margaret Kartomilta tietoja jaavalaisten lasten lauluista, olihan hän tutkinut niitäkin (Kartomi 1980, 1990, 2001). Olikin yllätys, että hän lähetti minulle kolme miehensä Hidris Kartomin muistamaa laulua II maailmansodan ajoilta. Hidris Kartomi eli lapsuutensa Banjarin kaupungissa Jaavalla (kartta 1) ja ne edustavat keskijaavalaista perinnettä. Laulut nuotinsi professori Kartomi ja ne ovat entuudestaan julkaisemattomia.

Nykyisin kaikki jaavalaiset ovat muslimeja. Saari jaetaan kolmeen kulttuurialueeseen, joista kullakin on oma historiansa. Indonesian pääkaupunki Jakarta sijaitsee saaren luoteisrannikolla. Tämän artikkelin kolme laulua ovat kulttuurisesti keskijaavalaisia, vaikka ne kuuluivat 1900-luvun puolivälissä Banjarin kaupungin traditioon Länsi- ja Keski-Jaavan rajalla.

Jaava jakautuu moniin historiallisesti muotoutuneisiin kulttuurialueisiin, joista voi lähemmin lukea mm. Reijo Lainelan (2010) tuoreesta tutkimuksesta. Saaren läntisin väestö puhuu sundaa, kun taas Keski- ja Itä-Jaavalla pääkielenä on jaava. Jaavan musiikkien erittäin laaja lähdeaineisto löytyy sarjasta The Garland Encyclopedia of World Music, Vol. 4, Southeast Asia (1998). Koska käsillä oleva kirjoitus keskittyy melodian analyysiin, jaavalaisuuden yleinen esittely jää syrjään. Sanottakoon kuitenkin, että jaavalaisten itsensä tulkitsemina heidän laulu- ja soitinmusiikkinsa pohjautuu pääosin kahteen säveljärjestelmään. Toinen on puoliaskeleita vailla oleva 5-sävelinen slendro, joka ilmenee kolmena patet-nimisenä muunnoksena. Toinen jär-

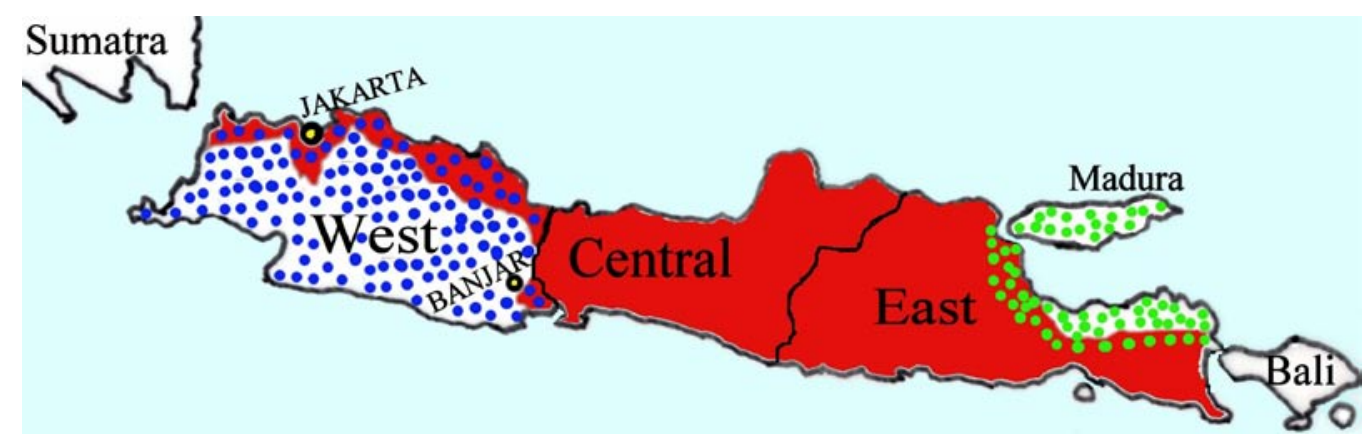

Kartta 1. Indonesiaan kuuluva Jaava sijaitsee Sumatran ja Balin välillä. Punaiset alueet osoittavat, missä kielenä on jaava, siniset pisteet tarkoittavat sundan kielen puhuma-aluetta ja vihreät maduran kielen puhuma-aluetta. Kielet ovat likeistä sukua. 
jestelmä on 7-sävelinen pelog, jonka ydin on niin ikään pentatonaalinen, mutta sellainen, jossa on puoliaskeleita. Sekin toteutuu kolmena patet-muunnoksena. (Kartomi 1973; Lainela 2010.) Jaavalaiselle laulutyylille ominaiseen esitystapaan kuuluu koristeellisuus, jossa mm. liukumien, heleiden, melismojen ja perinteisten sävelkulkujen avulla melodia muuntuu monimutkaiseksi.

\section{Tutkasävelteorian perusteita}

Analyysi pohjautuu Gerald Langnerin (Langner 2007; Langner ym. 2006; Rees \& Langner 2005; Langner 2004; Langner ym. 2003; Langner ym. 2002; Langner ym. 1997; Langner \& Schreiner 1988) neurofysiologisille päätelmille kuulokeskuksen toiminnan periaatteista, joista yksi on se, että harmonisen sävelen pohjasävel aktivoi joukon kuulosoluja, jotka suhteutuvat toisiinsa kuten mollikolmisointu. Yksinkertaistaen voidaan sanoa, että harmoninen sävel $g$ aktivoi keskikuuloaivon soluissa C-mollia vastaavan neurosoinnun. Tämä periaate on näiden jaavalaisten sävelmien analyysin perusta.

Olen pitkään rakentanut teoriaa, joka tätä nykyä alkaa olla valmis, joskin kokonaisvaltaista yleisesitystä vailla. Teorian nimenä oli kauan "siirtymäteoria", jonka kehkeytymisen vaiheista ja ongelmista professori Erkki Huovinen (2008) on kirjoittanut kriittisen ja perusteellisen arvion. Itseäni järkytti vuosikaudet se, että kykenin vaivatta analysoimaan minkä tahansa sävelmän käyttämällä kuutta heksatonaalista moodia ja niiden aihioita sitomalla ne "ankkurisäveleen", jona toimi bordunan tapaan melodian alla soiva dominanttisävel. Tämän kaltainen analyysi ei tuntunut käyvän järkeen, koska se oli yksinkertainen ja tehokas, mutta sen teoreettinen perustelu tuntui mahdottomalta. Tarkoitin "siirtymällä" sitä, että melodian aikana ankkurisävel saattoi siirtyä uuteen paikkaan, jolloin tapahtui joko modulaatio tai transpositio. Tämän artikkelin melodioita hallitsee kolmen heksatonaalisen moodin ainekset, joten esittelen vain ne nuottiesimerkissä 1 .

Kun esimerkiksi ensimmäisen heksatonaalisen moodin asteet suhteutuvat 4. astetta lukuun ottamatta toisiinsa kuten toonikan yläsävelet 6-10 ja 12, arvelin, että ihmisen laulumelodiat uusintavat yläsävelsarjan suhteita ja että ankkurisävelellä on kuulokeskuksessa vahva vaste. Tutustuminen Gerald Langnerin tutkimustuloksiin romutti pahasti kuvitelmaa "ankkurin" kuulosoluvasteesta. Hankalinta oli kuitenkin ymmärtää, miten ihminen kykenee mitenkään tajuamaan musiikkia tai puhetta, jos sävelen kuulosoluvasteena on pelkästään mollikolmisointu. Vielä 2008 

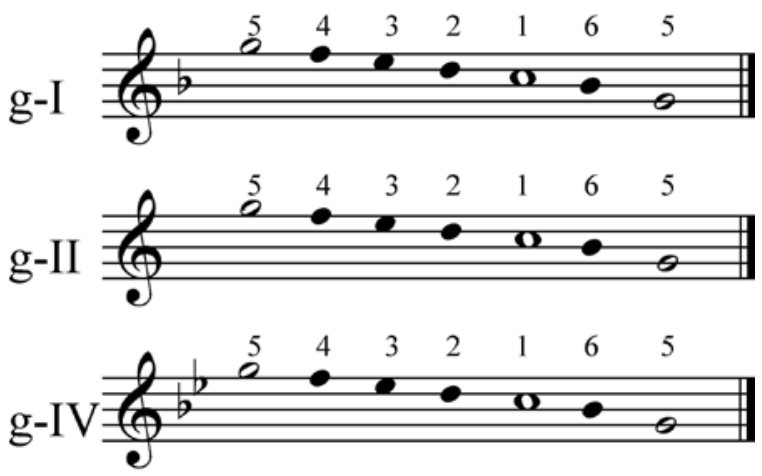

Nuottiesimerkki 1. Heksatonaaliset moodit g-I, g-II ja g-IV sijoitettuna G-horisonttiin, jolloin toonika on $c^{2}$ ja dominantti on $g^{1}$. Moodi g-II on tonaalisen C-duurin historiallinen juuri, g-IV on luonnollisen c-mollin juuri ja g-I on g-doorisen juuri, joka nousee suoraan kuulokeskuksen solujen reaktiokaavasta. Kaikkien moodien "ankkurina" eli bordunan tapaan soivana tutkasävelenä on siis dominantti $\mathrm{g}^{1}$.

pyrin selittämään kuulokeskuksen toimintaa yläsävelten avulla tässä vuosikirjassa (Leisiö 2008). Lopulta oli pakko hyväksyä Langnerin tulokset: kuulokeskus mittaa värähdyksen periodin (keston) ja luo tätä tietä mielikuvan sävelkorkeudesta. Toisin sanoen kuulokeskus käyttää pelkästään pohjasäveltä sävelkorkeuden määrittämiseen. Kuten Langnerin (2007) suomennetusta tutkielmasta käy selville, kuulokeskus järjestyy subharmonisesti. Matemaattisesti se on harmonisen peilikuva. Olen koonnut seuraavaan taulukkoon 1 analyysin kannalta keskeisten käsitteiden määritelmät.

Kuvan 1 tietoja oli kuitenkin hankala sijoittaa musiikkianalyysiini ja teoreettisen työskentelyn aikana tein lukuisia virheoletuksia. Asia alkoi hahmottua lopullisesti vasta vuoden 2010 alussa alettuani paremmin ymmärtää Langnerin monimutkaista teorianmuodostusta. Lopulta aloin ymmärtää, miten tutkasävel toimii ja miksi sen käyttö oli aina ollut keskeinen osa menetelmää, vaikka se ei kuulu melodiaan, ei voi tuottaa neurosointuja eikä tue yhtään mitään. Ja kuitenkin se on tehokas teoreettisena työvälineenä formalisoitaessa melodialle syntaksi. Sen avulla tutkija voi 


\begin{tabular}{|c|c|}
\hline arkki(toonika) & $\begin{array}{l}\text { Jos laulu perustuu yhdelle ainoalle sävelelle, sävel on arkki: sillä ei ole } \\
\text { analyysissä dominanttisäveltä ja tutkasävel on se itse. Arkkitoonika voi } \\
\text { asettua myös keskelle melodiaa. Säkeen päättävä dominanttisävel muuttuu } \\
\text { arkiksi, kuten laulujen analyysissä tullaan havaitsemaan. }\end{array}$ \\
\hline harmoninen sävel & Sävel, jonka aallonpituuden kesto pysyy muuttumattomana. Ks. periodi. \\
\hline harmoninen suhde & $\begin{array}{l}\text { Sävelet ovat harmonisessa suhteessa, kun niiden aallonpituuksien kestot } \\
\text { suhteutuvat toisiinsa kuten pienet kokonaisluvut }(2 \cdot 1,3 \cdot 1,4 \cdot 1 \text { jne.). Sama } \\
\text { suhde on taajuuksien välillä: } 100 \mathrm{~Hz}, 200 \mathrm{~Hz}, 400 \mathrm{~Hz}, 800 \mathrm{~Hz} \text {. }\end{array}$ \\
\hline millisekunti (ms.) & Sekunnin tuhannesosa. \\
\hline neuroni & Kuulosolu. \\
\hline neurosointu & $\begin{array}{l}\text { Harmonisen sävelen samanaikaisesti aktivoimien kuulosolujen kokonaisuus, } \\
\text { joka on aina mollimuotoinen. Sävel } c \text { aktivoi laskevasti solut C-As-F, jotka } \\
\text { muodostavat neurosoinnun Fm. Tämä on harmonisen sävelen kuulosoluvaste } \\
\text { ja johtaa universaalikaavaan } c=\mathrm{Fm} \text {. }\end{array}$ \\
\hline periodi & $\begin{array}{l}\text { Aallonpituuden eli värähdyksen ajallinen kesto. Jos sekunnissa toteutuu } 440 \\
\text { värähdystä }(440 \mathrm{~Hz}) \text {, periodi on 1:400 eli } 2,27 \text { millisekuntia. }\end{array}$ \\
\hline $\begin{array}{l}\text { subharmoninen } \\
\text { suhde }\end{array}$ & $\begin{array}{l}\text { Kun kuulosolujen väliset viritystilat suhteutuvat toisiinsa kuten pienet } \\
\text { kokonaisluvut niiden välillä on subharmoninen suhde. Nämä suhteet saadaan } \\
\text { kuvattua jakamalla. Sävel } c \text { aktivoi kolmen solukerroksen C solut (C, C:2, } \\
\text { C:4), kaksi F-solua (C:3, C:6) ja As-solun (C:5). }\end{array}$ \\
\hline syntaksi & $\begin{array}{l}\text { Termin pohjalla on kreikan syntaksis 'yhteen asettaminen'. Tässä se } \\
\text { tarkoittaa kunkin alueen paikallisia tapoja asettaa säveliä. Syntaksit ovat } \\
\text { sovinnaisia sääntöjä ja tutkasävelen avulla säännöt voidaan formalisoida. } \\
\text { Melodioiden vertailu tapahtuu syntakseja vertaamalla. }\end{array}$ \\
\hline tutkasävel & $\begin{array}{l}\text { Tutkasävel toimii syntaksin havaitsijana, tunnistajana ja määrittäjänä. Se on } \\
\text { teoreettinen, koska se ei kuulu melodiaan. Se kuitenkin toimii kuten } \\
\text { todellinen bordunasävel. Eli tutkasävel on aktiivitilassa niin kauan, kun } \\
\text { lauletut sävelet suhteutuvat siihen harmonisesti. Kun harmoninen suhde } \\
\text { katoaa, tutkijan on etsittävä uusi tutka, joka taas on harmonisessa suhteessa } \\
\text { laulettuihin säveliin (nuottiesimerkki 2). Tutkasävelteorian kuusi moodia } \\
\text { rakennetaan tutkasävelen varaan (nuottiesimerkki 1). }\end{array}$ \\
\hline
\end{tabular}

Taulukko 1. Keskeistä terminologiaa.

tarkastella, minkälaisissa (sub)harmonisissa suhteissa laulettu sävel etenee suhteessa kaikkiin laulettuihin säveliin sekä tähän teoreettiseen bordunaan.

Langnerin kokeiden yksi keskeisistä tuloksista on siis se, että kuulokeskuksen solut sisältävät suuren joukon aivosähköisiä impulsseja, jotka siirtyvät tumakkeelta toiselle kuvan 3 mukaisesti. Kun kyse on peräkkäisistä sävelkorkeuksista, tätä kaaosta järjestelee keskeisimmin keskiaivojen alakukkulan yhteensattumasolukko, 


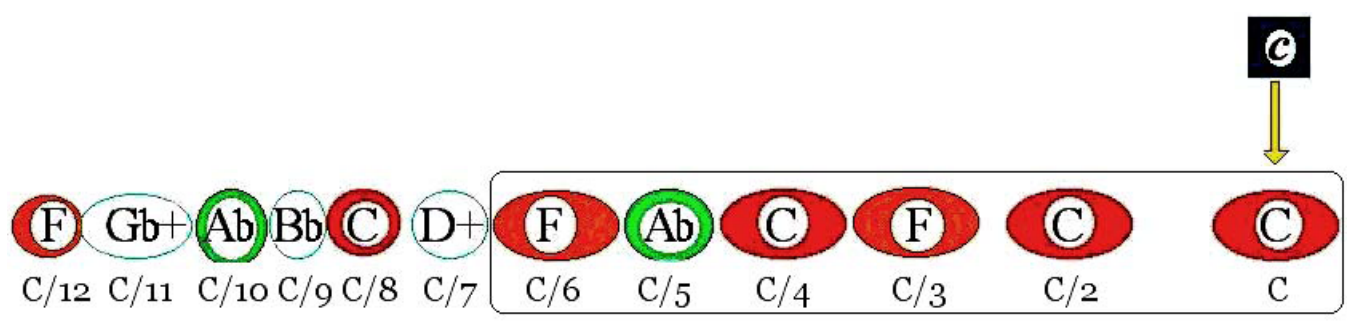

Kuva 1. Yläoikealla oleva harmoninen sävel $c$ aktivoi aina kuulosoluja tämän matemaattisen kaavan mukaan (lue oikealta vasemmalle). Vahvimmin aktivoituu se C-solu, joka on virittynyt tämän sävelen periodille (jaksolle eli kestolle). Se aktivoituu, mutta samalla aktivoituu viisi muutakin solua. Subharmoninen sarja jatkuu vasemmalle, mutta kuulokeskuksessa aktivoituvat vain ensimmäiset 5 tai 6 sävelille $c$-c-f-c-as-f virittynyttä soluja. Sävelen $c$ soluvasteena on siis neurosointu F-molli (vrt. kuva 2). Huomaa, että sävelnimet kirjoitetaan pienillä kirjaimilla, niitä vastaavat kuulosolut suurilla (F, F-molli).

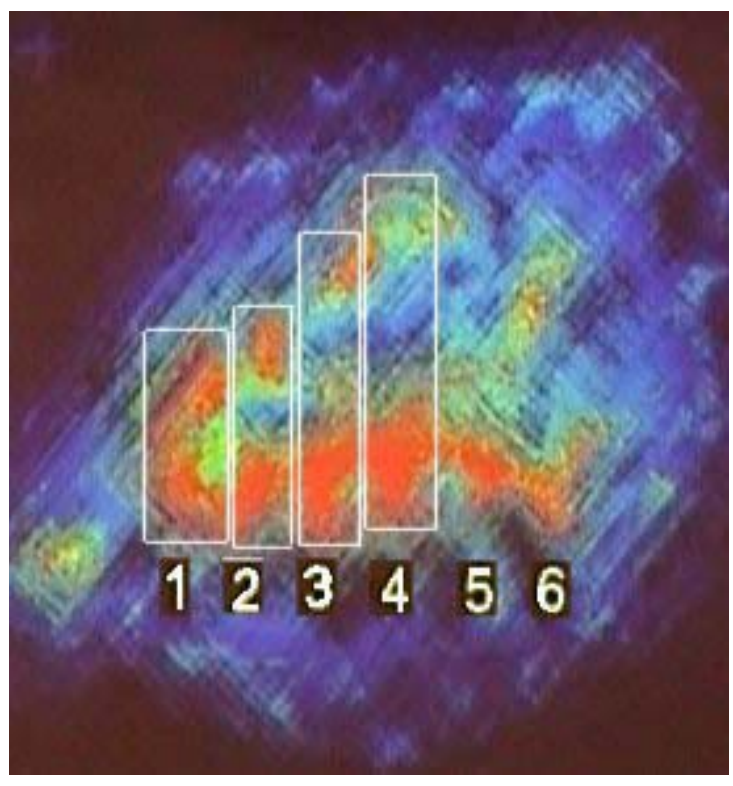

Kuva 2. Hyppyrotan keskiaivojen alakukkulan (Colliculus inferior) aktivoituminen, kun siihen suunnataan 400 Hz:n eli lähellä $g^{1}$ :tä soiva harmoninen sävel. Numerot 1-6 on sijoitettu vaakatasossa etenevien subharmonisten aktivoitumispisteiden alapuolelle. Ne ovat G-G:2-G:3 jne. ja ne vastaavat neurosointua C-molli (G-G-C-G-Es-C). Kuvasta näkyy, että 6. solualue oikealla aktivoituu muita heikommin. Yhdessä pisteessä aktivoituu satoja, jos ei tuhansia soluja. Valkoisella viivalla rajatut pystysuorat alueet osoittavat sävelen spektrin (äänenvärikartan eli tonotopian), josta erottuu neljä vahvaa formanttialuetta. (Vrt. Langner 2007: 227-230.) Tämän ennen julkaisemattoman kuvan käsittely ja tulkinta ovat kirjoittajan ja se julkaistaan Langnerin luvalla. 
jonka toimintaperiaate näkyy kuvan 3 oikealla puolella. Ylinnä oleva käyrä esittää simpukan käsittelemän sävelen spektriä, joka luo mielikuvan äänenväristä. Nämä impulssit siirtyvät simpukkatumakkeeseen, jossa yhdistelijäpiirin solut alkavat purkautua säännöllisen periodisesti eli kerran kunkin värähdyksen alussa. Tämä purkaus (piikki) siirtyy yhteensattumasoluun. Simpukkatumakkeessa samaa simpukasta tulevaa impulssia käsittelee myös värähtelypiiri, joka purkautuu yhden periodin aikana moneen kertaan viiveellisinä pulsseina. Tämä perustuu siihen, että harmonisella sävelellä on vakaa periodi (pohjasävel), mutta sillä on myös kaksi tai useampaa vahvaa yläsäveltä, joilla on yhteinen verhokäyrä ja joista kukin värähtelee ajallisesti samaan aikaan ikään kuin toinen toisiinsa sekoittuneina. Kuvassa 3 värähtelypiiristä lähteviä purkauksia on kuvattu kolme kappaletta. Nämä purkaukset ovat suurten kokonaislukujen $(1,2,3,4,5,6)$ suhteessa yhdistelijäpiirin periodiin. Niin kuin kaikki yläsävelet toteutuvat yhden periodin aikana (ja yhden verhokäyrän sisällä) samoin

\section{Kuulokeskus}

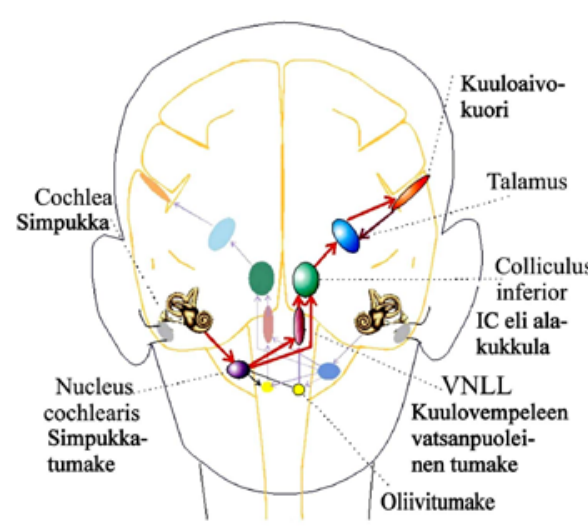

\section{Kuulosolujen jaksoanalyysi}

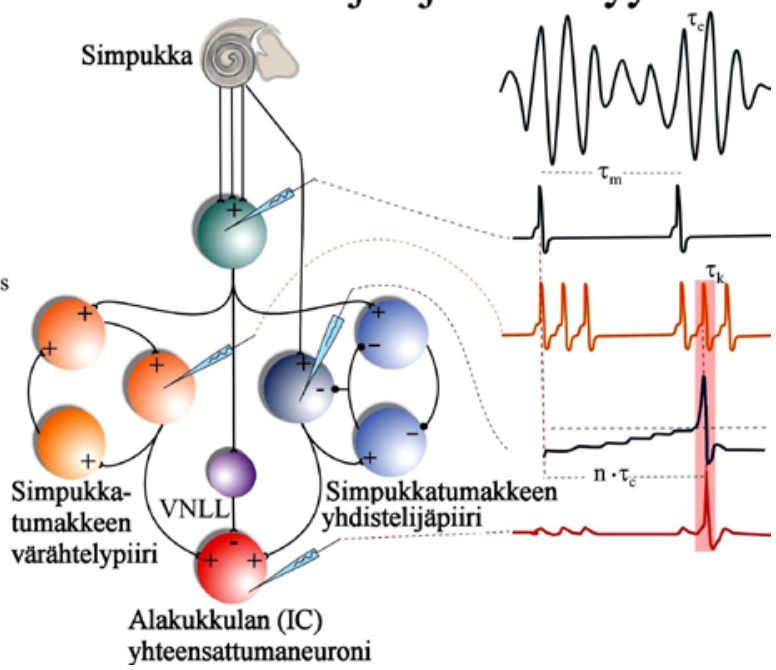

Kuva 3. Vasemmalla on kuulokeskus ja sen keskeiset osat. Oikealla näkyy, miten Langnerin teorian mukaan alimpana näkyvän alakukkulan yhteensattumasolu aktivoituu, kun siihen saapuu samanaikaisesti kaksi simpukkatumakkeen eri solulähteestä saapuvaa sellaista impulssia, jotka suhteutuvat toisiinsa kuten pienimmät kokonaisluvut, pääosin 1-2-3-4-5, mutta myös 6. (Langner 2007: 219, kuva 2 ja 222, kuva 3.) 
värähtelypiirin purkaukset tapahtuvat yhdistelijäpiirin yhden periodin aikana. Koska viiveelliset piikit ovat harmonisessa suhteessa sekä toisiinsa että yhdistelijäpiirin piikkiin yhteensattumasolu aktivoituu hetkellä, jolloin se ottaa vastaan kummatkin piikit samalla hetkellä. Tätä tietä yhteensattumasolut mittavat periodin (sen kahden piikin välisen ajan) ja tämä tulos siirtyy korteksille, jossa syntyy tietoisuus sävelkorkeudesta. Melodian edetessä prosessit siirtyvät muistiin ja kuulija kokee musiikin etenevän luontevasti, jos peräkkäiset sävelet suhteutuvat toisiinsa saman kokonaislukuperiaatteen mukaan. Siis musiikin tajuamisessa muisti on keskeisessä asemassa. Luonnollisesti kysymys melodian "luontevuudesta" on tyystin suhteellista, paikallista ja kulttuurista - toisinkin kuin yhteensattumasolujen toiminta, joka on sama kaikilla nisäkkäillä, myös ihmisellä (kuva 3). Mutta mikä yhdellä alueella koetaan luontevaksi, ei toisella alueella sitä ole. Tutkasävelteorian avulla pyritään kuitenkin selittämään melodioiden sisäistä logiikkaa etsimällä niitä ohjailevat syntaksit.

Kuvassa 4 esitetään yhdistelijäpiirin toiminta kahden vuorottelevan solun (2A ja 2B) avulla. Tämä sen vuoksi, että solu joutuu aktivoiduttuaan lepäämään, jolloin on viereisen solun vuoro aktivoitua. Kuulija kokee sävelkorkeuden sen mukaan, miten pitkä tai lyhyt yhteensattumasolun impulssien $\left(\tau_{k}\right)$ välinen kesto (periodi) on. Kuvan 4 prosessi tapahtuu, kuten myös neurosointu syntyy, ilman yläsäveliäkin, mutta jos yläsäveliä on, yhteensattumasolu saa vahvoja energiapulsseja, koska se saa niitä useista harmonisissa suhteissa toisiinsa olevista samanaikaisista lähteistä. Näin esimerkiksi c:n 3. äänes on $g$, joka aktivoi ainakin solut G, G:2, G:4, G:8, jotka kaikki ovat subharmonisessa suhteessa soluun C. Yhteensattumaneuronit erittelevät ennen kaikkea peräkkäisten sävelten virtaa niin musiikissa kuin puheessa. Kun signaali koostuu useasta samanaikaisesta sävelestä, vaikka neliäänisen kuoron laulusta tai pianon soinnuista, analyysin suorittaa alakukkulassa siihen erikoistunut joukko harmonian erittelijäsoluja. Niiden toimintaperiaate on kuitenkin sama kuin edellä: ne aktivoituvat hetkellä, jolloin niihin saapuu kaksi tai useampi impulssi, jotka ajallisesti suhteutuvat toisiinsa kuin pienimmät kokonaisluvut. Mitä yksinkertaisempi on suhdeluku, sitä harmonisemmalta eli konsonoivammalta sointu kuulostaa. Tässä tulee mukaan tutkasävelen käytön neurologinen selitys.

Tutkasävel on teoreettisesti määritettävissä oleva sävel, joka toimii tutkijan apuvälineenä etsittäessä melodianmuodostuksen pohjana olevaa syntaksia eli säännöstöä. Tutkasävelen käytön loogisena perustana ovat samojen pienten kokonaislukujen muodostamat suhdeluvut, joiden pohjalta yhteensattumaneuroneissa ja soinnullisuuden tunnistinsoluissa syntyy impulssi. Asiaa voi valaista nuottiesimerkin 2 

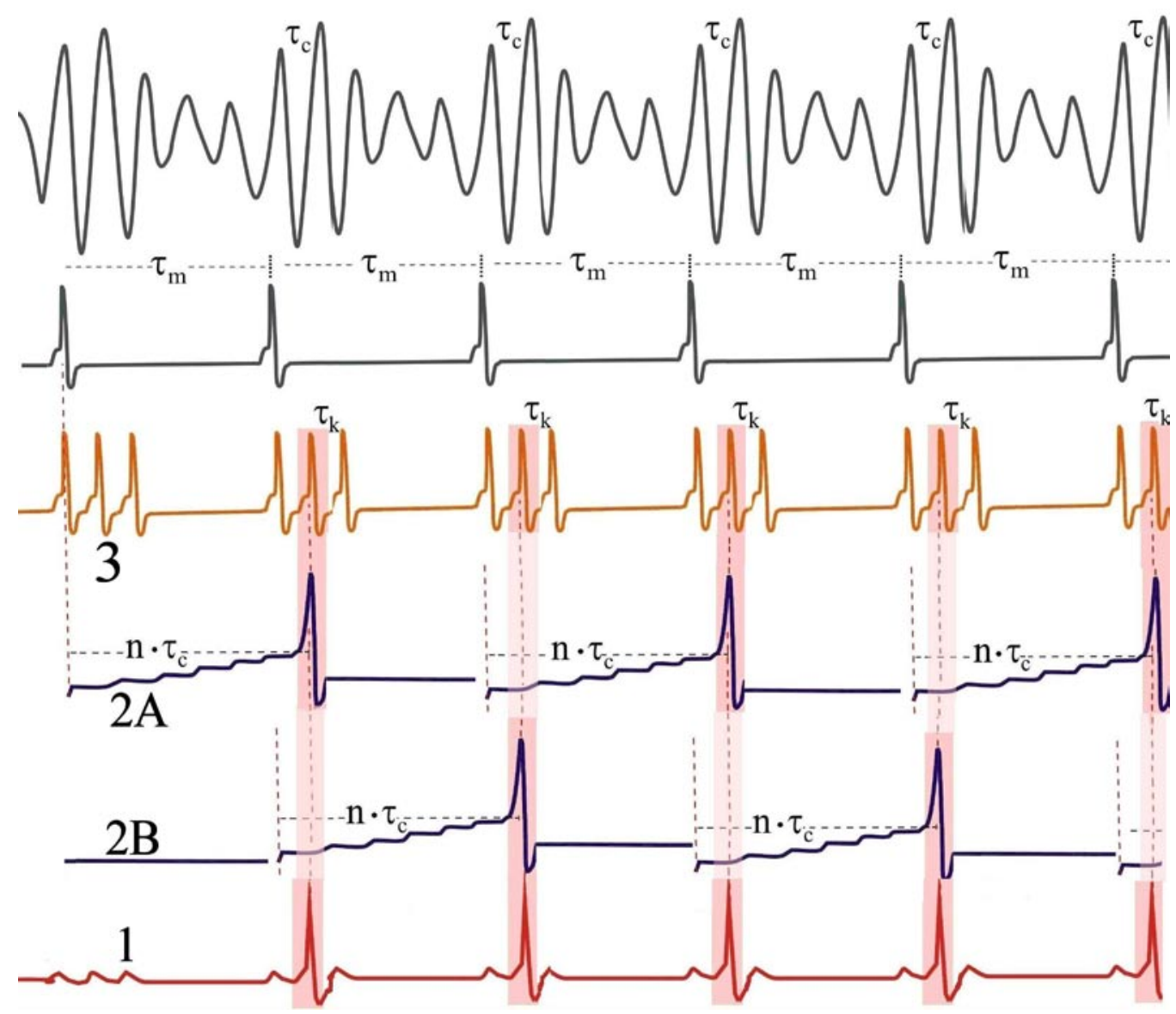

Kuva 4. Simpukkatumakkeen värähtelypiirin (käyrä no. 3) viiveelliset impulssit ja yhdistelijäpiirin (käyrät $2 \mathrm{~A}$ ja $2 \mathrm{~B}$ ) viiveetön perusimpulssi siirtyvät hetkellä $\tau_{\mathrm{k}}$ yhteensattumaneuroniin (alin käyrä 1), joka aktivoituu säännöllisin väliajoin ja alakukkulassa tapahtuu periodien tarkka kestomittaus. Yksi periodi on siis alimman käyrän (1) kahden piikin välinen aika. Kirjoittaja on muokannut tämän jatkamalla Langnerin alkuperäisen kuvan prosessia eteenpäin.

avulla. Luvut vastaavat luonnollisen virityksen suhteita. Nuottiesimerkin 2 yläriviä voi lukea myös siten, minkälaisissa suhteissa moodien g-I, g-II ja g-IV lauletut sävelet ovat sävelellä g${ }^{1}$ soivaan bordunaan.

Musiikintutkimuksen oppihistoriassa etnomusikologian yhdeksi "isäksi" korotettu psykologi Carl Stumpf pohti konsonanssin olemusta. Äänipsykologiaa käsit- 
televässä teoksessaan (1890 ja 1897) hän esitti, että kahden sävelen muodostama konsonanssipari (priimi, oktaavi, kvintti, kvartti, terssit ja sekstit) muodostaa yhden sävelyksikön tuloksena prosessista, jota hän kutsui sävelten sulautumaksi. Hän ei kyennyt täysin selittämään sulauman luonnetta. Stumpfin teoriaan palasi Martin Ebeling (2007, 2008 ja 2009), joka julkaisi konsonanssia ja dissonanssia selittävän matemaattisen mallin sen pohjalta, miten Langnerin teoriassa keskikuuloaivojen solut toimivat määrittäessään jaksollisuutta eli periodisuutta autokorrelaation avulla. Ebelingin matematiikka tukee vahvasti Langnerin tuloksia, mutta samalla se vahvistaa Stumpfin psykologista sulaumateoriaa neurofysiologiaa selittävän matematiikan avulla. Ebelingin tutkimuskohteena ei ollut sävel, vaan kahden sävelen muodostama intervalli. Langnerin yhtenä löytönä oli alakukkulan kuulosolujen suorittama autokorrelaatio. Kun samanaikaisesti soi kaksi säveltä, joilla on eri periodit, kuulosolut luovat omat periodinsa, joiden pohjalta eriperiodisuus muuntuu yhdeksi periodiksi. Langner selitti neurofysiologisesti Stumpfin sulautuman. Ebeling puolestaan selitti kuulosolujen keinot laskea ja määrittää uudet maksimipiikit niiden omien matemaattisten ratkaisujensa avulla. Lopulta myös Ebelingin matemaattiset ratkaisut voidaan palauttaa nuottiesimerkin 2 suhdelukuihin.

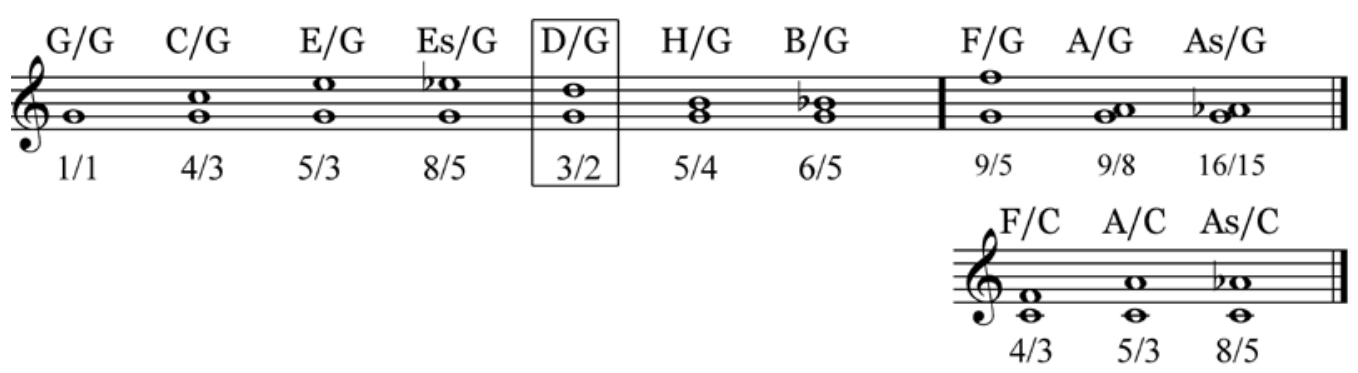

Nuottiesimerkki 2. Laulettujen sävelten suhteet todelliseen bordunaan G-horisontissa. Ylärivin kirjainpareista (G/G, C/G, E/G jne.) edellinen merkitsee laulettua säveltä ja jälkimmäinen soivaa bordunaa $g^{1}$. Ensitahdin sarjassa poikkeuksena on viides pari D/G. Viivaston alapuolella näkyvät luonnollisen viritysjärjestelmän sävelparien suhdeluvut, jotka osoittavat, että nuottiesimerkissä 1 olevan kolmen heksatonaalisen moodin lauletut sävelet suhteutuvat pienten kokonaislukujen suhteessa bordunaan. Ylärivin toisessa tahdissa suhdeluvut monimutkaistuvat, eikä sävelten $f$, $a$ ja as vasteita löydy g:n neurosoinnusta $\mathrm{Cm}$. Toisen tahdin sävelparit vaativat bordunasävelen vaihtoa, ja alaviivasto osoittaa, että uutena bordunana on $c$ ja uutena toonikana on $f$. 
Vielä tiivistäen: simpukassa tapahtuvan harmonisen sävelen äänesten analyysin seurauksena kuulosoluihin siirtyy suuri joukko sähköisiä impulsseja, jotka pakkautuvat autokorrelaation perusteella histogrammin tapaisiksi säännöllisesti maksimeiksi, joiden periodit vastaavat kuultua sävelkorkeutta. Jos kahden samanaikaisen sävelen maksimijono ei etene säännöllisesti, intervalli dissonoi. (Ebeling 2008 ja 2009.) Tämä on aivan keskeistä tutkasävelen ymmärtämiseksi. Tutkimuksessa tutkasävel on se sävel, jonka kanssa laulettu sävel muodostaa kaksisävelisen soinnun. Jos sointu ei voisi muodostua konsonanssiksi, tutkan on oltava muualla ja tutkijan on löydettävä sävel, joka kykenee jälleen muodostamaan konsonanssin laulettujen sävelten kanssa.
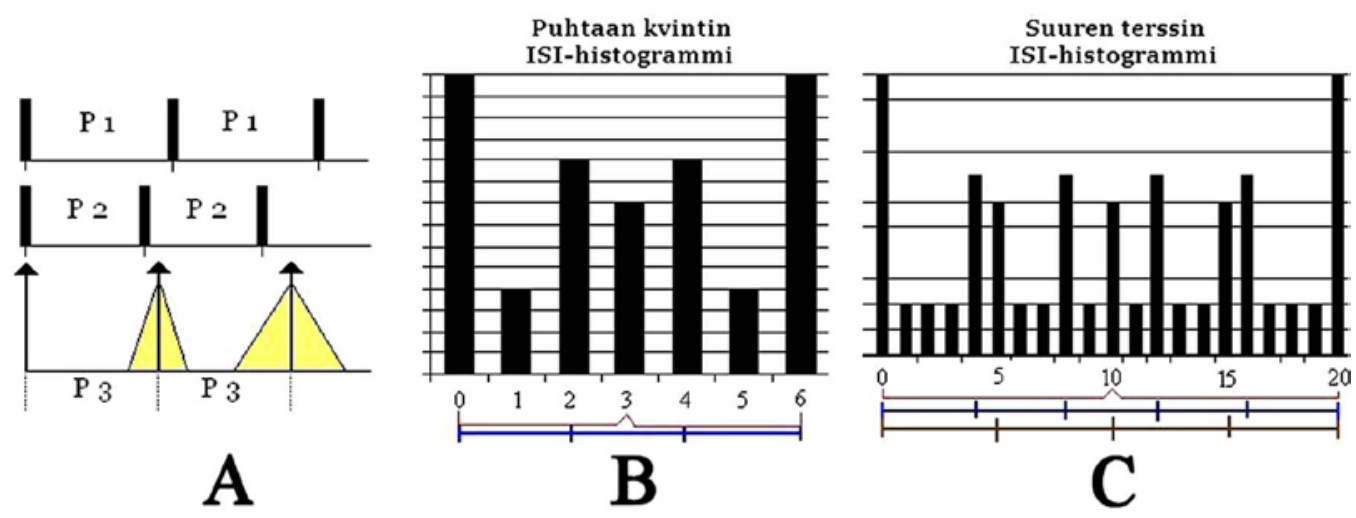

Kuva 5. Kuulosolujen toteuttaman autokorrelaation periaate. A. Tässä on kaksi samanaikaisesti soivaa säveltä, joiden eripituiset periodit ovat P1 ja P2. Keskiaivojen kuulokeskus kokoaa näistä palikkamaisista impulssimaksimeista omat maksiminsa: autokorrelaation tuloksena syntyy kolmiomaisten aktivaatiopiikkien välille periodi P3. B. Keskellä on Martin Ebelingin kuvio puhtaasta kvintistä, jonka periodin autokorrelaatio jakaa kuuteen harmoniseen piikkiin, joiden väliset suhteet ovat 1:6, 2:6 ja 3:6 = 1:6, 1:3 ja 1:2. (ISI = Interspike Interval). C. Martin Ebelingin kuva suuresta terssistä, jonka periodi jakautuu kuulosolujen autokorrelaation vuoksi 20 osaan. Tuloksena ovat harmoniset suhteet 1:20, 4:20 (sininen), 5:20 (ruskea) ja 10:20 (punainen) = 1:5, 1:4 ja 1:2. Kuvissa B ja C piikkien pitäisi näyttää kolmioilta, mutta ne on tilasyistä piirretty palikoiksi. Kuvat julkaistaan Martin Ebelingin luvalla. Autokorrelaatio tapahtuu värähtelypiirin tuottamia sykäyksiä jakamalla. Jakamisen toimittavat kuulosolut, ei tutkija, joka vain formalisoi prosessit kuviksi. 


\section{Neurosoinnut ja moodit}

Kirjoituksessa kierrän matematiikan ennen kaikkea sen vuoksi, että päämääränä on melodian analyysi, ei neurofysiologia. Tämä on täysin mahdollista, koska samaan päämäärään voidaan päästä kahta eri tietä. Toinen on havainnollistaa lauletun sävelen suhde bordunaan luonnollisten intervallien klassisten suhdelukujen avulla. Toinen on neurosointujen käyttö, koska neurosoinnut havainnollistavat musiikintutkijalle kaiken oleellisen ilman, että mitään muutetaan matematiikaksi.

Nuottiesimerkistä 2 näkyy, että g-borduna muodostaa ylärivin ensitahdissa vahvoja suhteita (priimi, kvartti, sekstit ja terssit sekä kvintti) laulettuihin säveliin. Vahvin konsonanssi on priimi G/G (1:1, jolloin borduna ja laulettu sävel ovat sama) ja heikoin on pieni terssi B/G (6:5). Jo Stumpf oli havainnut, että seksteillä on likeinen yhteys tersseihin, mutta hänellä oli vaikeuksia antaa tälle selitys. Kun asiaa tarkastellaan subharmonisesti aktivoituvien solujen kannalta, havaitaan, että lauletun sävelen sekstisuhde tutkaan aktivoi kuulokeskuksessa myös terssisuhteen ja päinvastoin. Pienen sekstin es ${ }^{2}-\mathrm{g}^{1}$ suhdeluku on 8:5. Toisaalta oktaavia alempaa lauletun sävelen es ${ }^{1}$ suhde samaan bordunaan $\mathrm{g}^{1}$ on suuri terssi 5:4. Neuronaalisesti tilanne näyttää hieman toiselta. Kuten kuva 1 paljastaa, laulettu sävel aktivoi neurosointunsa. Tässä tapauksessa laulettu es ${ }^{2}$ aktivoi Es-solun ohella sen subharmoniset oktaavikerrannaiset Es:2 ja Es:4, mikä merkitsee, että kuulosoluissa aktivoituu myös suuren terssin suhde 5:4 (ks. kuva 6). Näin siis lauletun es ${ }^{2}$-sävelen aktivoima Es-solu on samanaikaisesti pienen sekstin päässä g-bordunan G-solusta kun Es:2 on suuren terssin päässä samasta G-solusta. Vastaavasti lauletun $\mathrm{e}^{2}$-sävelen solu E on samanaikaisesti suuren sekstin päässä bordunan aktivoimasta G-solusta kun E:2 on pienen terssin päässä samaisesta G-solusta. Stumpf oli saanut aikaan omat tuloksensa soittamalla koehenkilöilleen sävelpareja. Keskiaivojen alakukkulan solut tunnistivat parit, mutta aktivoituivat siten, että terssisuhde tuotti samalla myös sekstisuhteen ja sekstisuhde terssisuhteen. Koska yhteensattumasolut reagoivat kokonaislukujen kerrannaisiin, (2-4-8, 3-6-9-12, 4-8-12, 5-10) kuulokeskuksen kannalta suhteet 8:5 = 4:5 = 2:5 ovat identtiset ja synnyttävät mielikuvan pienestä sekstistä samalla, kun ne synnyttävät suuren terssin soluvasteena suhteet 6:5 =3:5.

Nuottiesimerkin 2 lauletut sävelet ovat ensimmäisessä tahdissa harmonisessa suhteessa g-bordunaan, jonka kanssa ne yhdessä muodostavat konsonansseja. Konsonanssit näkyvät myös suhdelukuina, jotka ovat 1:1, 2:1, 3:2, 4:3, 5:3, 5:4, 6:5 ja 8:5. Nämä suhdeluvut hallitsevat moodien g-I, g-II ja g-IV asteiden 5, 6, 1 ja 3 suhdetta 
Laulettu sävel $e^{2}$ Keskellä on bordunan aktivoima G-solu $e: n$ aktivoima solu E:2

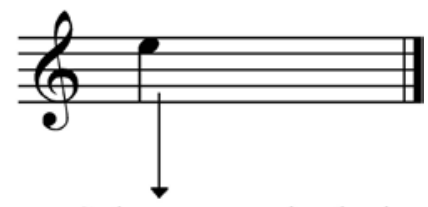

$e: n$ aktivoima solu $\mathrm{E}$

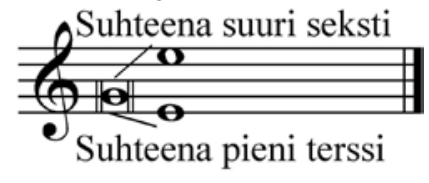

Laulettu sävel $e s^{2}$

$e s: n$ aktivoima solu Es
Keskellä on bordunan aktivoima G-solu es:n aktivoima solu Es:2
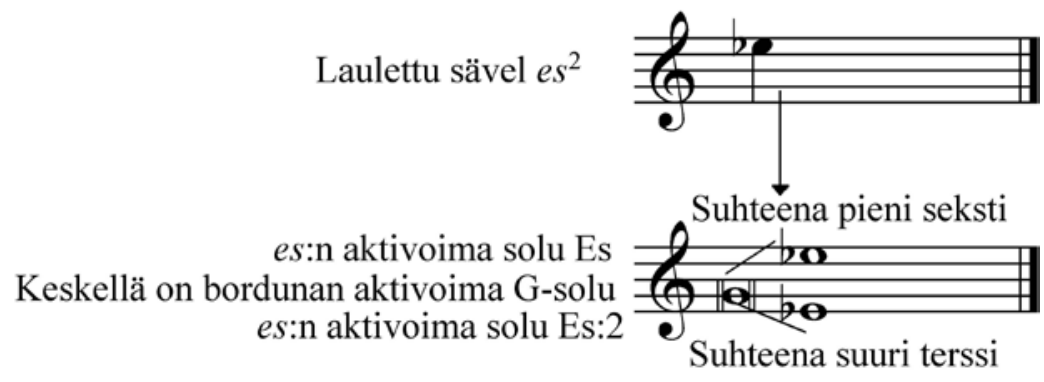

Kuva 6. Sekstin ja terssin neuronaalinen sukulaisuus G-horisontissa, jossa borduna on dominanttisävel $g^{1}$ ja laulettuina sävelinä on ensin $\mathrm{e}^{2}$ ja sitten $\mathrm{es}^{2}$. Toonika on kummassakin $\mathrm{c}^{2}$. Subharmonisia soluja E:4 ja Es:4 tässä ei erikseen näytetä, mutta ne ovat laulettujen sävelten aktivoimina ikään kuin vielä yhtä oktaavia matalammalla.

bordunaan g1. Tutkasävelteoriassa tutkasävel seuraa melodianliikettä kuin se olisi todellinen borduna. Tutka on kuvitteellinen borduna, joka reagoi laulettuun säveleen samojen suhdelukujen avulla kuin todellinen borduna. Luetellut 8 suhdelukua tarkoittavat tutkasävelteoriassa sitä, että bordunan tapaan kuvitteellisenkin tutkan voi sanoa tukevan laulettuja säveliä. Analyysissä käsitettä tuki voidaan kuvata myös kuvitteellisen tutkan muodostamilla kuvitteellisilla neurosoinnuilla, mutta nekin toimivat metaforisina kuvaimina, jotka viime kädessä palautuvat yhteensattumasolut aktivoiville pienimmille kokonaislukusuhteille.

Nuottiesimerkin 2 ensitahdissa on kuitenkin yksi intervalli, kvintti $\mathrm{g}^{1}-\mathrm{d}^{2}$, joka on ongelmallinen suhteessa bordunaan $\mathrm{g} 1$. Suhde on tietenkin 3:2, mutta se muodostuu ongelmaksi neuronaalisen todellisuuden näkökulmasta. Bordunan g-sävel 
aktivoi neurosoinnun Cm (C-Es-G), kun taas laulettu $\mathrm{d}^{2}$ aktivoi neurosoinnun Gm (G-B-D). Kun nuottiesimerkin 2 ensitahdin intervalleista kaikkien borduna on dominanttisävelellä g, lauletut sävelet suhtautuivat harmonisesti dominanttiin tilanteessa, jossa toonikana on $\mathrm{c}^{2}$. Suhteessa $\mathrm{g}^{1}-\mathrm{d}^{2}$ tilanne on toinen siitä huolimatta, että melodia pysyy edelleen G-horisontissa, mikä tila saa todisteensa siitä, että $\mathrm{d}^{2}$ :n ilmaantuessa melodiaan g-sävel säilyy edelleen bordunana. Tässä tapahtuu modaalinen käännös, jonka voi tunnistaa ainoastaan neuronaalisesti, ja tämä on otettava analyysissä vakavasti, koska kuulokeskus on ainoa väline, jonka avulla voimme olla yhteydessä akustisiin prosesseihin. Mitä siis tapahtuu?

Kun suhde $\mathrm{g}^{1}-\mathrm{d}^{2}$ soi, kuulokeskuksessa aktivoituvat solut ovat G-B-D/C-Es-G. Ensinnäkin soinnun tunnistajasolu aktivoituu vahvan kvintin G-D ja heikon (alaspäisen) kvintin B-Es vuoksi. Toiseksi G-solu aktivoituu vahvemmin kuin mikään muu solu. Ensinnäkin sen aktivoi borduna g1, mutta myös laulettu d ${ }^{2}$, jonka neurosoinnussa G-solu aktivoituu subharmonisissa pisteissä D:3 ja D:6. Yleistäen voi sanoa, että kun melodia etenee moodien g-I, g-II ja g-IV asteilla 5, 6, 1 ja 3, nämä asteet ovat harmonisissa suhteissa dominanttibordunaan $g$, joka pitää kaiken aikaa aktiivisena C-solua. Solu C on neuraalinen neksus, sitojasolu, joka vastaa akustista toonikaa $\mathrm{c}^{2}$. Mutta kun melodiaan ilmaantuu 2. aste, $\mathrm{d}^{2}$, sen aikana neksus on Gsolu, jonka vastineena oleva g 1 muuttuu toonikaksi. Modaalinen käännös syntyy siis silloin, kun borduna ja toonika ovat sama sävel. Kun uutena toonikana on g1, uutena dominanttina on sen alapuolinen $\mathrm{d}^{1}$, ja näin todellisuudessa laulettu $\mathrm{d}^{2}$ onkin dominantin yläoktaavi.

Yksiäänisessä melodiassa ei ole bordunaa, eikä yksiäänisessä melodiassa d ${ }^{2}$ aktivoi G-solua sen vahvemmin kuin mikään muukaan sävel aktivoi kolmatta subharmonista soluaan. Säestyksetön yksiääninen melodia kuitenkin etenee neurosoinnuin ja pitää tietyt solut selkeämmin aktiivisina sitojina kuin muut solut. Kun melodia otetaan analyysin kohteeksi, analyysin pohjana täytyy olla teoria, ja teorioista yhden muodostaa tutkasävelteoria, jonka keskeisin työväline on todellisen bordunan teoreettinen simulaatio, tutkasävel. Käännöstä ei saa esille kuin bordunan ja lauletun sävelen välisen neuraalisen suhteen avulla. Melodian 2. asteeseen ei kuitenkaan tarvitse kiinnittää huomiota silloin, kun se ilmaantuu hetkellisenä sivusävelenä kuten mikä tahansa muu aste. Tilanne kuitenkin muuttuu, jos käänteisyys alkaa hallita melodianmuodostusta pitkän aikaa. Tällöin analyysissä tilanne ilmaistaan lisäämällä moodin symboliin käänteinen kysymysmerkki $i$. 
On huomattava, että käänteisen moodin asteikko on täsmälleen sama kuin sen luonnollisen moodin asteikko. Aihion g-*II sävelet ovat nousevasti $\mathrm{g}^{1}-\mathrm{h}^{1}-\mathrm{c}^{2}-\mathrm{d}^{2}-$ $\mathrm{e}^{2}$ ja samat sävelet ovat sen käänteisellä asulla g- ${ }^{*}$ ¿II. Erona on se, että edellisessä toonikana on $c^{2}$ ja dominanttibordunana on $g^{1}$, kun taas käännöksen todellisena (neuronaalisesti todennettavana) toonikana on edelleenkin bordunana toimiva g1 ja dominanttina on $\mathrm{d}^{1}$. Kiintoisana yksityiskohtana on se, että tutkimissani lauluissa aihion -*$^{*}$ ¿II ollessa aktiivisena ei laisinkaan esiinny säveltä $\mathrm{d}^{1}$, vaan aina sen yläoktaavi d ${ }^{2}$. Käänteisen g- $^{*}$ ¿II:n aikana melodiaa hallitsevat asteet ovat 5, 6 ja 2, jotka kaikki tukevat toonika g:tä, ja joiden aikana toonikan $c^{2}$ on mahdoton ilmaantua melodiaan.

Käänteisissä moodeissa kvintti 2-5 $\left(\mathrm{d}^{2}-\mathrm{g}^{1}\right)$ tapahtuu todellisuudessa D-horisontissa, koska todellinen dominantti on näennäinen 2. aste d. Luonnollisessa Ghorisontissakin syntyy bordunan suhteen yksi täsmälleen samanlainen kvintti eli pudotus dominantilta toonikalle: $\mathrm{g}^{1}-\mathrm{c}^{1}$. Kiintoisaa on, että se näyttää olevan globaalisti epätavallinen ja leimaavan aivan tiettyjen laulukulttuureiden syntaksia. Tavanomaisen analyysin kannalta liikkeessä dominantilta alas toonikalle ei pitäisi olla kerrassa mitään epätavallista, mutta tutkasävelteorian valossa näin vain on.

Tutkasävelteorian avulla analyysi etenee kuuden kantamoodin avulla. Tässä ajaudutaan tutkasävelteorian seuraavaan keskeiseen piirteeseen, heksatonaalisten moodien vuorotteluun, joka ominaisuus oli syynä teorian entiseen nimeen "siirtymäteoria". Tämän selittämiseksi on palattava nuottiesimerkin 2 ylärivin jälkimmäiseen tahtiin, jossa $g^{1}$-borduna muodostaa parit sävelten $f^{2}, a^{1}$ ja as ${ }^{1}$ kanssa. Septimisuhde G/F on 9:5. Se koostuu jaottomista luvuista ja on sen verran monimutkainen, että kuulokeskus hyväksyy $f$-sävelen kerrallisena sivusävelenä suhteessa $g$ :hen, muttei muuta. Kyse on tutusta asiasta. G-duurisoinnun aikana voidaan laulaa sivusävelenä $f$, mutta jos melodia painottaa säveliä $f-a-c$, G-duuri täytyy vaihtaa F-duuriksi. Langnerin nisäkäskokeissa 9. subharmoninen solukaista ei aktivoidu, mikä osoittaa sen olevan liian monimutkaisessa suhteessa 5:een. Jos säveltä $f$ ei tulkitakaan tonaalisessa mielessä C-duurin asteeksi 4, on miettiminen, mitä se on. Kun kyse ei ole hetkellisestä sivusävelestä, joka on g-pohjaisenkin heksatonaalisen moodin aste 4, tämä sävel $f$ on uusi toonika ja täten uutena dominanttina on $c$. Kuten nuottiesimerkin 2 alarivi näyttää, suhde 9:5 muuttuu suhteeksi 4:3 (F/C), joka on uuden $c$-dominantin suhde uuteen $f$-toonikaan. Tämä sopii erinomaisesti Langnerin teoriaan, jonka mukaan subharmonisesti järjestyvässä kuulosolusarjassa asteiden 3 ja 5 eli C:5 ja C:6 ei tapahdu aktivaatiota. Tonaalisessa moniäänisessä musiikissa 4. aste ei ole ongelma, koska 
sitä on mahdollista tukea mitä erilaisimmin sointumuunnoksin jazzista sinfoniseen tyyliin. Yksiäänisessä laulussa vaihtoehtoja ei ole. Heksatonaalinen 4. aste $f$ on uusi toonika ja silloin sen dominanttina ja bordunasävelenä voi olla vain $c$.

Nuottiesimerkin 2 kakkostahdin suhde A/G on kuten suhde G:9/G:8 eli 9:8, joka on dissonanssi. Tämä näkyy myös siitä, että samaan aikaan kuulokeskuksessa aktivoituvat neurosoinnut olisivat $\mathrm{Cm}$ ja Dm, joita yksikään yhteinen solu ei sido. Tässä mielessä $g$-borduna ei tue laulettua $a$ :ta. Ylärivin viimeisin pari As/G on vielä dissonoivampi ja vastaa suhdetta G:16/G:15 eli 16/15. Jos lauletut sävelet $a$ ja as suhteutetaan c-bordunaan (mikä näkyy nuottiesimerkin 2 alarivillä) suhteet muuttuvat sekstisuhteiksi 5:3 ja 8:5. Kun uudeksi bordunaksi valitaan $c$, laulettu $f$ on uusi toonika. Tällöin laulettu $a$ onkin moodien c-I ja c-II kolmas aste, kun taas as on moodin $c$-IV kolmas aste. On siis tapahtunut siirtymä G-horisontista C-horisonttiin.

Tutkasävelteorian termein nuottiesimerkin 2 suhdeluvut 9:8 ja 16:15 tarkoittavat, ettei G-horisontissa olevan heksatonaalisen moodin asteiden 5 ja 6 ( $g-b$ tai $g-h)$ väliin voi asettua säveltä. Suhde $g-b$ (neuraalinen 6:5) on heikko mutta riittävä. Sen sijaan suhteet $g$-as ja $g$ - $a$ ovat niin dissonoivia, että ne pakottavat vaihtamaan bordunan muualle. Myös neurosoinnun subharmoninen rakenne viittaa samaan: G-horisontissa asteiden 5 ja 6 välinen suhde on sama kuin solujen G:5 ja G:6 välinen suhde, eikä kokonaislukujen 5 ja 6 väliin mahdu muuta kokonaislukua. Suhde ei ole yhtä tiukka asteiden 4 ja $5(f-g)$ välillä, minkä vuoksi aste 4 kuuluu yksittäisinä sivusävelinä globaalisti melodioihin. Sen sijaan sävelet $a$ tai $a$ s eivät ensikään esiinny G-horisontissa - eivät edes fennoskandinaavisissa viulupolskissa, vaikka viululla olisi täysin vaivatonta soittaa toonika $c: n$ ja dominantti g:n väliin myös $a \sim a s$. Näin ei vain ole tapahtunut. Tonaalinen 6 . aste alkoi ilmaantua kansansävelmien notaatioihin vasta pianosäestyksisten nuottien myötä 1800-luvun lopulla. Tämä johtuu siitä, että pianolla on vaivaton soittaa sävel $a \sim a s$, koska kuulokeskus saa sille vahvan tuen lukuisilla melodiaan kuulumattomilla soinnuilla.

Rameau osui naulan kantaan valitessaan 5. asteen nimeksi dominantti siitä huolimatta, ettei toonika laisinkaan aktivoi dominanttisäveltä vastaavaa solua. Rameau rakensi tonaalisen teoriansa cembalolla ja tuli jo varhain vakuuttuneeksi siitä, että melodia ja sointu ovat erottamaton kokonaisuus. Dominantti on valtasävel sen vuoksi, että sen tuottama neurosointu pitää toonikaa vastaavat kuulosolut alati aktiiveina. Cembalon soittama dominantti g tuottaa todellisen $\mathrm{Cm}$-neurosoinnun ja solujen $\mathrm{C}$ ja $\mathrm{G}$ (sävelten $\mathrm{g}^{1} \mathrm{ja} \mathrm{c}^{1}$ ) välinen kvintti on 3:2. On kuitenkin huomattava, ettei kyseisellä sävelellä g1 ole yhteyttä c-toonikan aktivoimaan neurosointuun, vaan G-solu kuu- 
luu g-toonikan synnyttämään neurosointuun. Tämä tarkoittaa, että kun tonaalisessa teoriassa c-toonikan dominantti on g, neuraalitodellisuudessa c-toonikan rinnalla on toinenkin toonika eli cembalon soittama g, joka aktivoi C:n. Dominanttisävel on moniäänisen tonaalisen musiikin alituisesti soiva bordunasävel, koska se kuuluu sekä toonikan että dominantin kolmisointuun. Näin ei ole neuronaalisessa todellisuudessa, joka on fysikaalisen (tonaalisen) peilikuva. Sen vuoksi dominantin sijasta neuronaalisena bordunana onkin toonikaa vastaava solu C eli neksus, koska se sisältyy näiden neurosointuihin Cm ja Fm. Yksiäänisessä laulumusiikissakin kaikki on toisin kuin moniäänisessä. Koska yksiääninen sävelmä etenee vain peräkkäisinä neurosointuina, moniäänisen musiikin bordunasäveltä ei synny. Tämän vuoksi tutkasävelteoriaan pohjautuvaan typologisoivaan menetelmään otetaan mukaan teoreettinen borduna eli tutkasävel, jonka käytön logiikka pohjaa konsonanssin ja dissonanssin samoille suhdeluvuille kuin todellisen bordunan käyttö.

Tonaalisen tulkinnan kannalta saattaa vaikuttaa omituiselta, että suhde $g-f$ on dissonanssi, joka vaatii tutkanvaihtoa, kun taas soinnullisessa musiikissa G7 soi miellyttävän harmonisesti. Septimisoinnun G7 rakenne on vahva, koska sen sävelet asettuvat toistensa suhteen kuten $g$-sävelen subharmoniset pisteet G:9-G:7-G:6-G:5 (solut

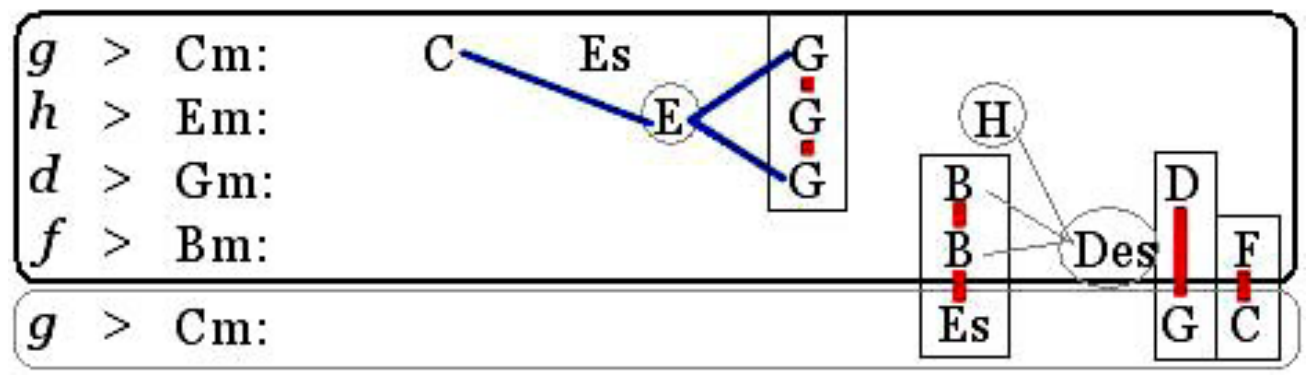

Kuva 7. G-duurin septimisoinnun neuronaalinen rakenne. Vasemmalla olevien sävelten neurosoinnut annetaan tässä vaakatasossa (Cm: C-Es-G jne.). Sointu on vahva, koska G-neuroni saa ärsykkeen kolmesta lähteestä (< Cm, Em, Gm). B-neuroni saa ärsykkeen kahdesta samanaikaisesta lähteestä $(<\mathrm{Gm}, \mathrm{Bm})$. Kun lisätään $g$-sävelen neurosointu $\mathrm{Cm}$ uudelleen sointukuvaimen alapuolelle, havaitaan, miten Bm:n B-solun ja Cm:n Es-solun välinen suhde on 3:2. Gm:n D-solun ja Cm:n G-solun välinen suhde on niin ikään 3:2, joka on myös Bm:n F-solun ja Cm:n C-solun välillä. Myös solut E, H ja Des muodostavat samanaikaisesti ärsytystilassa olevien solujen kanssa terssisuhteita. E-solun suhde C:hen ja Des-solun suhde B:hen on 5:4, ja sen suhde kahdelta suunnalta aktivoituun G:hen on 6:5, joka pätee myös H- ja Des-solun välillä. 
F-A-C-As). Toisaalta soinnun sävelistä $g$ aktivoi Cm:n, $h$ aktivoi Em:n, $d$ aktivoi Gm: n ja $f$ aktivoi Bm:n. Kuva 7 havainnollistaa tämän neurosointujen avulla. Ensinnäkin G- ja B-solut saavat hyvin vahvat ärsykkeet, jotka aktivoivat alakukkulan soinnun erittelijäneuronit samalla, kun toiset neuronit aktivoituvat samanaikaisten suhteiden 3:2, 4:3 ja 6:5 vuoksi. Näyttää siltä, että G7-soinnun aktivoimista solukaistoista yksikään ei jää leskitilaan: kaikilla kaistoilla on sellainen aktiivinen vastinkaista, joka laukaisee jonkin neuronin, ja kaikki minkä ne aktivoivat, siirtyy tietoisuuteen. Tämä osoittanee, miten suuresti yksiäänisen ja moniäänisen melodian kuuloaivovasteet eroavat toisistaan. Nelisävelinen septimisointu G7 muuntuu tajunnassa vahvasti harmoniseksi, kun taas bordunasävelellä säestetyssä musiikissa sävelten $f$ ja $g$ välinen suhde 9:5 ei kykene aktivoimaan yhteensattumaneuronia. Tämä koskee myös teoreettista tutkasäveltä, jonka paikka tulee siis määrittää uudelleen.

Todellisuudessa laulajat eivät missään päin maailmaa muodosta melodioita kuuden heksatonaalisten kantamoodien avulla, vaan käyttävät suppeita heksatonaalisia aihioita, joissa säveliä voi olla vaikkapa vain 3-5 niin, että asteet 6 ja 3 ovat aina niiden joukossa. On myös melodioita, joista puuttuu aste 6 tai aste 3: vaikka laulettuja sävelasteita olisi neljä, melodian modaliteetti jää määrittämättä, koska vaihtoehtoja on aina vähintään kaksi. Tällaisia modaalisesti määrittämättömien sävelikköjen lajinimenä on alleeli. Kuitenkin jokainen alleeli voidaan sekä määrittää että nimetä täsmällisesti.

Melodiahan voi edetä siten, että nykyhetkellä aktiivinen tutka lopettaa tukemasta sekä laulettuja säveliä että toonikaa. Tämä on merkkinä siitä, että toonika on muuttanut paikkaansa, mikä merkitsee myös tutkan siirtyneen uuteen paikkaan. Tutkijan onkin kyettävä määrittämään seuraava tutkasävel ja sen avulla seuraava moodi. Kun tonaalisessa analyysissä melodiaa tarkastellaan suhteessa toonikaan ja analyysi etenee makromodaalisten rakenteiden varassa, heksatonaalisessa analyysissä tarkastelu etenee dominantin suhteen ja rekisteröi tutkasävelen jokaisen siirtymän. Makromodaalisella rakenteella tarkoitan $\mathrm{mm}$. duuria, molleja sekä gregoriaanisia kirkkomoodeja, slendroa, pelogia kuten myös esimerkiksi râgoja ja maqâmeja, jotka ovat enemmän tai vähemmän teoreettisia sopimuksia. Näillä ei ole asemaa tutkasävelteoriaan pohjaavassa analyysissä, koska menetelmä jakaa ne osiinsa tutkasävelvaihdosten myötä. Tätä kautta syntyvä siirtymäsarja (ks. nuottiesimerkkiä 3) on sama kuin syntaksi.

Tämän tutkimuksen päämääränä on siis tunnistaa ensin tyylille ominaiset tutkasävelet, sitten määrittää niiden avulla modaliteetit, ja tätä tietä ymmärtää, miten sävelmät on rakennettu. Jos laulun sävelinä ovat vain moodin g-II asteet 5-6-1-2-3 


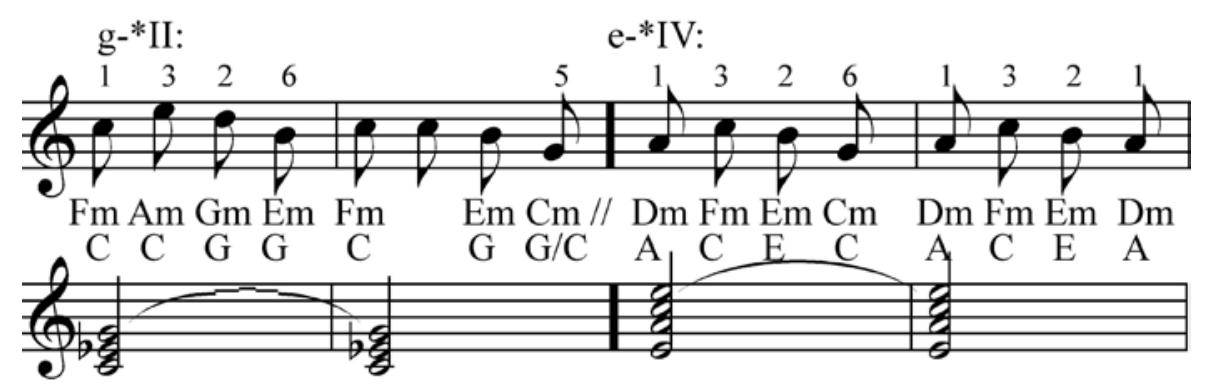

Nuottiesimerkki 3. Yläviivastolla oleva melodia moduloituu aihiosta g-*II aihioon e*IV. Tutkasävelten $g$ ja $e$ aktivoimat neurosoinnut $\mathrm{Cm}$ ja Am näkyvät puolinuotteina alaviivastolla. Ylinnä näkyvät pienet numerot tarkoittavat aihioiden asteita, ja mollisoinnut Fm, Am jne. tarkoittavat laulettujen sävelten synnyttämiä neurosointuja. Isot kirjaimet alaviivaston päällä osoittavat, mitkä kuulosolut aktivoituvat sekä laulettujen sävelten että tutkasävelten $g$ ja $e$ samanaikaisista impulsseista. Vaikka tutkasävelet $g^{1}$ ja $e^{1}$ ovat kuvitteellisia, niitä käsitellään kuten todellisia bordunasäveliä.

siten, että aloitus- ja päätössävelenä on toonika, tällöin syntaksia kuvaava kaava on g-*II $1 \rightarrow 1$. Tähti * tarkoittaa, että käytetyistä sävelistä puuttuu 4 . aste. Tällöin kyse ei ole heksatonaalisesta moodista vaan sen pentatonaalisesta aihiosta. Jos päätössävelenä olisi dominantti $g^{1}$, syntaksin kaavana olisi $g^{*}{ }^{*} I^{1} \rightarrow_{5}$. Jos taas melodia etenee kuten nuottiesimerkissä 3, syntaksi on erilainen, koska siinä tapahtuu modulaatio aihiosta *II aihioon *IV.

Kun aihio g-* II on myös C-duurin aihio ja e-*${ }^{*} I V$ on myös a-mollin aihio, melodian voi katsoa siirtyvän C-duurista a-molliin. Tonaalinen tulkinta toimii tässä aivan hyvin, mutta siirryttäessä ulkoeurooppalaisiin syntakseihin ongelmia alkaa nousta liikaa. Siksi myös nuottiesimerkki 3:n melodia on paras tulkita universaalivälineillä. Tällöin sen syntaksin kaavana on g-* ${ }^{-} 1^{1} \rightarrow_{5} \triangleleft$ - $^{*} \mathrm{IV}^{1} \rightarrow 1$, jossa nuoli $\downarrow$ tarkoittaa tutkan laskeutumista g1:ltä e ${ }^{1}: 1$ le ja jossa aihion e-* IV sävelet ovat $e^{1}-g^{1}-A^{1}-b^{1}-c^{2}$. Toonika $a^{1}$ ilmaistaan isolla kirjaimella $A^{1}$. Keskeistä on muistaa, että jos melodia asettuu äkkiä aihion asteiden 5 ja 6 väliin, melodialla onkin uusi toonika uudessa paikassa ja on siis tapahtunut joko modulaatio tai transpositio. Asteiden 5 ja 6 väliin ei voi asettua säveltä, koska tutka ei sitä tue. Nuottiesimerkissä 3 tutka $g(>\mathrm{Cm})$ ei siis tue tahdin 3 alussa asteiden 5 ja 6 väliin asettuvaa säveltä $a(>$ Dm). Paljastuu, että sävel $a^{1}$ onkin uusi toonika ja että sävel $e^{1}$ on uusi dominantti ja tutkasävel. 
Tätä kautta tulee esiin toinen keskeinen merkitys, joka tukea-verbillä on tutkasävelteoriassa. Nuottiesimerkin 3 kolmannen ja neljännen tahdin säveliä tukee $e$-tutkan aktivoima neurosointu Am (A-C-E). Kolmannessa tahdissa laulettujen sävelten $a^{1}-c^{2}-b^{1}$ voi sanoa olevan subharmonisessa suhteessa sekä toisiinsa että tutkaan, koska ne kaikki aktivoivat samat neuronit A-C-E, jotka taas ovat samat kuin tutkan subharmonisesti järjestyvät solukaistat A-C-E (=E:6-E:5-E:4).

Siirryn nyt tutkimaan melodian syntaktisia periaatteita kolmen tapaustutkimuksen avulla. Analysoin kolme keskijaavalaista lastenlaulua, Lagu dolanan pendhisil, Kupu kuwé (Kupu kuning) ja Gajah, jotka muusikko Hidris Kartomi muisti 1950-luvulla lauletun Banjarin kaupungissa. Laulut tallensi huhti- ja toukokuussa 2010 Margaret Kartomi, joka myös teki nuotinnokset sekä yhdisti runot melodiaan. Melodiat julkaistaan nyt ensimmäisen kerran.

\section{Lagu dolanan pendhisil}

Margaret Kartomin mukaan Lagu dolanan pendhisil runon keskeinen idea on seuraava: "Lapset, älkää eksykö lähdettyänne apinakärryillä huviretkelle - varokaa muukalaisia ja pahoja henkiä!" Laulu opastaa lapsia karttamaan vaaroja, ja sen englanninkielinen käännös onkin ytimekkäästi 'Lost' eli 'Kateissa'. Jaavalaisen tulkinnan mukaan laulun modaalisena perustana on pelog patet nem eli pelog-järjestelmän nem-muunnos (nuottiesimerkki 4).

Jaavalainen syntaksi eroaa niin paljon eurooppalaisesta, että ensi alkuun kirjoittajalla oli vaikea ymmärtää, miten melodia asettuu G-horisonttiin ja mitä modaalisia aineksia siinä on. Vähitellen sen syntaksi alkoi selkeytyä, ja siinä näkyy muutamia erikoisia paikallispiirteitä, joita esimerkiksi eurooppalaisesta traditiosta on vaikea löytää.

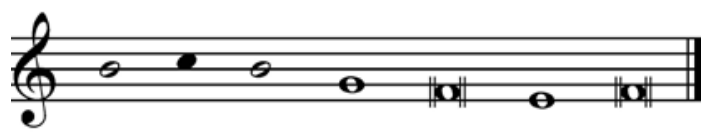

Nuottiesimerkki 4. Pelog patet nem. Jaavalaisen näkemyksen mukaan laulu Lagu dolanan pendhisil nuottiesimerkissä 5 pohjautuu näin järjestyvän moodin sävelille. 

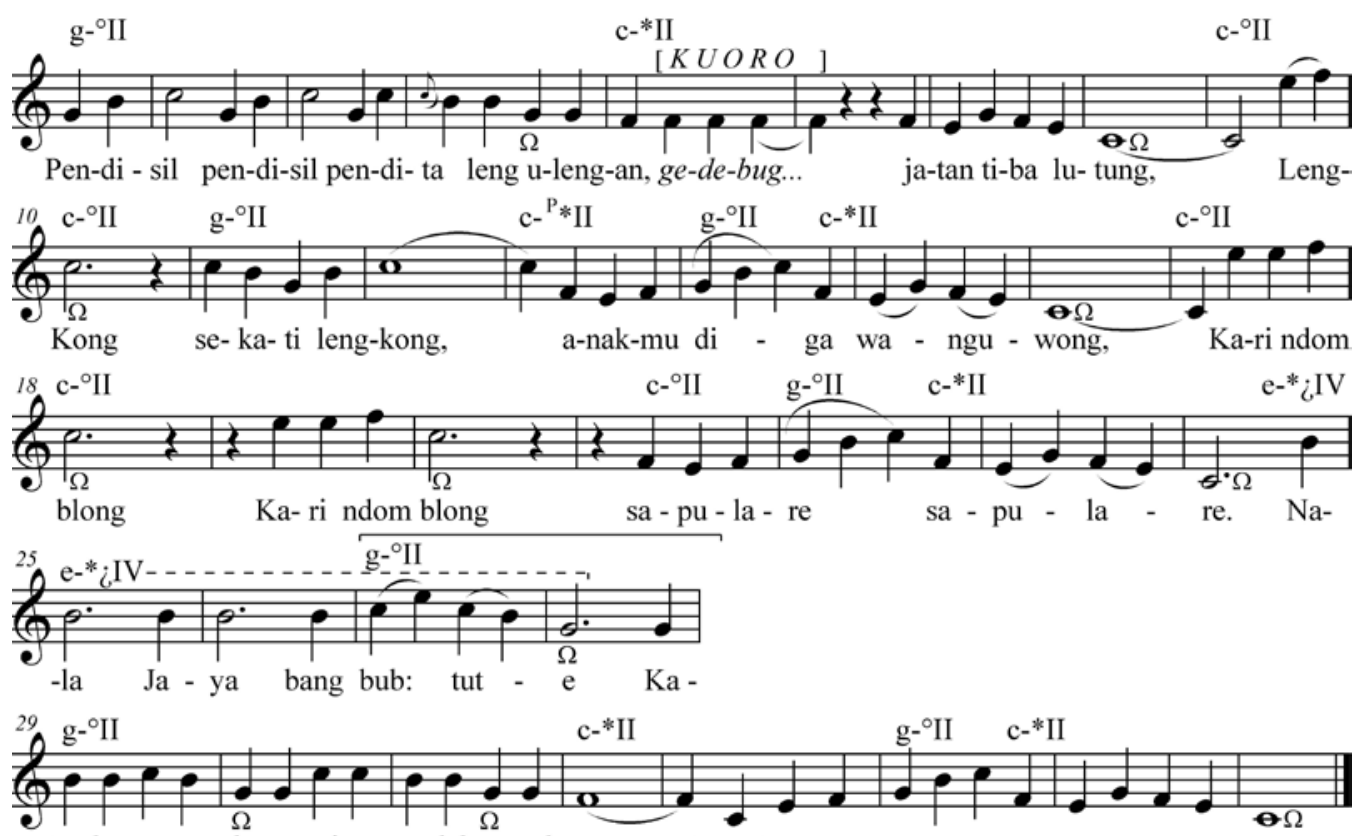

- te la-ra ngam-be wa-ni-ne ce-dak u-mah e.

Dong dong dong brus sa-pa Ka- ri kem-pas-kem-pus

Nuottiesimerkki 5. Keskijaavalainen lastenlaulu Lagu dolanan pendhisil. Nuotinnoksen teki Margaret Kartomi huhtikuussa 2010, analyysi on kirjoittajan. Selitykset ovat päätekstissä, mutta huomaa, että vuorottelevat tutkasävelet ovat vain $g$ ja $c$. Muutamat omega- eli $\Omega$-kirjaimet viivastojen alapuolella viittaavat arkkitoonikaan. Tämä on itsenäinen, muista riippumaton sävel, jolla ei ole dominanttia ja joka on itsensä tutkasävel.

Ensimmäiseksi on todettava, että laulun kantavana ideana on vaihdella yhtä ja samaa aihiota kolmella eri korkeudella siten, että aihion määrittävä dominantti vuorottelee sävelillä $g^{1}-_{-c}{ }_{-c}^{2}{ }_{-g}$. Tätä havainnollistaa nuottiesimerkki $6 \mathrm{~A}$, josta paljastuu, että laulaja vie melodiaa eteenpäin kolmisäveliköillä, kun tutkana on $g^{1}$ ja $c^{2}$, ja nelisäveliköllä, kun tutkana on $c^{1}$. Lisäksi nuo säveliköt muodostavat yhden ja saman heksatonaalisen markkerin eli kolmisävelikön, joka muodostuu asteista 5-6-1 $\left(g^{1}-h^{1}-c^{2} ; c^{2}-e^{2}-f^{2}=\right.$ suuri terssi + pieni sekunti), ja joka etenee sekä ylös- että alaspäin. Kun heksatonaalisen markkerin symbolina on ${ }^{\circ}$, aihioiden syntaktiset symbolit ovat yksinkertaisesti g- ${ }^{\circ} \mathrm{II}$ ja c- ${ }^{\circ} \mathrm{II}$ (vrt. nuottiesimerkki 1).

Melodiassa ei esiinny laisinkaan säveltä $d$. Edellä nuottiesimerkin 2 yhteydessä osoitettiin, ettei asteiden 5 ja 6 välissä voi olla säveltä. Koska $c^{2}$ on aihion c-II tutka, säveltä $d^{1}$ tai $d^{2}$ ei esiinny. Samasta syystä aihion $g^{-*}$ II yhteydessä ei voi olla säveltä 


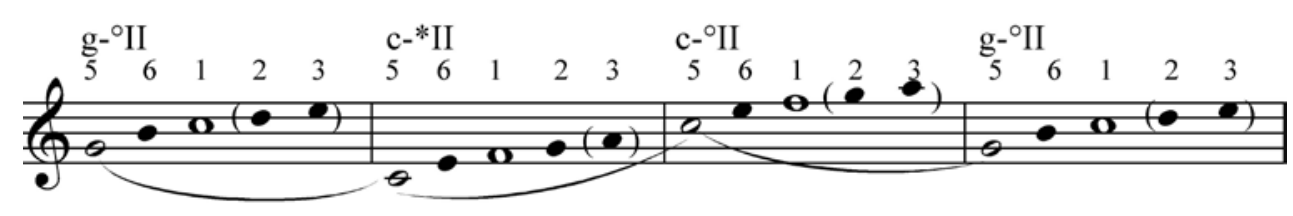

Nuottiesimerkki 6A. Laulun Lagu dolanan pendhisil syntaktisena pohja-ajatuksena on liikutella aihiota *II tutkasävelten $g$ ja $c$ varassa käyttämällä siirtointervalleina kvinttiä $g^{1}-c^{1}$, oktaavia $c^{1}-c^{2}$ ja kvarttia $c^{2}-g^{1}$. Suluissa olevia asteita ei melodiassa lauleta. Symbolit g- ${ }^{\circ}$ II ja c- ${ }^{\circ}$ II tarkoittavat, että melodia muodostuu pelkästään kolmisävelisten markkereiden asteista 5-6-1. Näin siis markkerin symboli ${ }^{\circ}$ korvaa aihion tähtisymbolin *. Pieni kokonuotti on dominantti ja suuri kokonuotti on toonika.

$a^{1}$. Sävel $a^{1}$ voisi ilmaantua nuottiesimerkin 5 rivillä 4 . Siinähän tapahtuu muulle melodialle kontrastiivinen modulaatio mollimaiseen aihioon e- ${ }^{*} \mathrm{IV}$, jonka toonika on $a^{1}$. Melodia on kuitenkin muotoiltu siten, että moodi on käänteinen $e^{-*} i \mathrm{IV}$, mikä näkyy siinä, että toonikana ja tutkasävelenä on $e^{1}$, jolloin luonnollisen $e^{-*} \mathrm{IV}$-aihion $a$-toonika ei pääse kuuluville. Täten melodia on pentatonaalinen: oktaavi jakautuu viiteen intervalliin.

Jos ollaan tarkkoja, markkereita g-II ja c-II kuten myös nelisävelistä aihiota $g$-*II $^{*}$ tulisi käsitellä alleeleina, koska niistä puuttuu 3. aste. Kuitenkin suuren terssin sisältämä markkeri voi johtaa vain duurin aihioon $\mathrm{g}^{*}$ II tai harmonisen mollin aihioon g-*III. Koska harmonisen mollin aihiosta ei toistaiseksi ole löytynyt Jaavalla viitettä, on turvallista yksinkertaistaa analyysiä määrittämällä alleelit aihioiksi *II eikä alleeleiksi. Täten laulun yhtenä keskeisideana on saman aihion vuorottelu (nuottiesimerkki 6B)

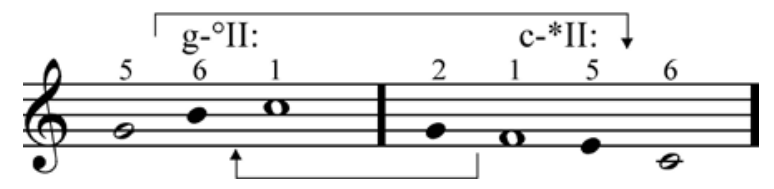

Nuottiesimerkki 6B: Laulun Lagu dolanan pendhisil (nuottiesimerkki 5) ylimmän rivin syntaksin ideana on kahden peilikuvamaisen aihion vuorottelu. Ne ovat liki identtiset, mutta kvintin päässä $\left(g^{1}-c^{1}\right)$ toisistaan. Vuorottelun idea säilyy myöhemmillä riveillä. 
Melodian kokonaisrakenteelle oleellisena piirteenä on 3. rivin lopussa käynnistyvä modulaatio käänteiselle aihiolle $e^{-*}$ ¿IV. Tonaalisella kielellä voi sanoa että tapahtuu modulaatio duurista luonnolliseen molliin ja takaisin. Neljännen rivin prosessi näkyy nuottiesimerkissä 6C. Jo näköhavainto paljastaa, ettei tutkana voi olla c eikä $g$, vaan $e^{1}$. Uusi aihio $e_{-}^{*}$ IV koostuu sävelistä $e^{1}-g^{1}-A^{1}-h^{1}-c^{2}-e^{2}$, jolloin aloittava sävel $h^{1}$ on sen 2. aste. Melodian kulku sisältää kolme kiintoisaa piirrettä, jotka selittävät sekä tämän sävelmäyksilön että jaavalaisen syntaksin luonnetta yleisemminkin. Nuottiesimerkin 6C ensimmäisenä piirteenä on melodian käänteisyys, mikä johtuu siitä, että sen kolmessa ensitahdissa E-soluun kohdistuu pitkäaikaisin ärsytys samalla, kun $e$-sävel toimii tutkana. Sävelen $d^{2}$ puuttumista selitettiin aihion $c^{-*}$ II kannalta jo edellä, mutta tässä kontekstissa $d^{2}$ olisi 4 . aste, jota $e$-tutka ei tue ja joka jätetäänkin laulamatta. Moodin käänteisyyden vuoksi toonikakin jää laulamatta ja nuottiesimerkin 6C neurosoinnuista näkyy, ettei sitä vastaava A-solukaan aktivoidu kuin kerran sävelen $e^{2}$ soidessa. Kun sekä $a$ että $d$-sävel jäävät laulamatta, tuloksena on viehättävä pentatonaalinen melodiakaarre, jota puolisävelaskel leimaa.

Toisena leimallisena piirteenä on modaalinen lomittuminen. Esimerkiksi eurooppalaiselle syntaksille on ominaista, että modulaation ja transposition tapahtumahetki on yleensä määritettävissä - paitsi, jos se tapahtuu 4. asteen soidessa, jolloin tuo aste kuuluu sekä päättyvään että käynnistyvään moodiin. Lagu dolanan pendhisil laulussa siirtymä uuteen rakenteeseen tapahtuu siten, että sekä vanha että uusi aines ovat jonkin aikaa lomittuneina. Nuottiesimerkissä 6C tämä näkyy tahdeissa 3 ja 4 . Yhtäältä kaikki neljä tahtia etenevät aihion $e^{-*}$ ¿IV sävelillä, mutta painokas päätössävel $g^{1}$ on aihion 6. aste, jonka käyttö finaliksena ei ole motivoitu. Sen suhde tutkaan

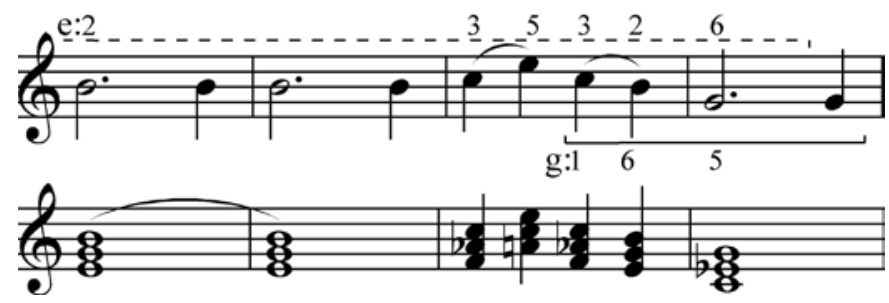

Nuottiesimerkki 6C. Lagu dolanan pendhisil -laulun tahdit 25-28. Laulettujen sävelten aktivoimat neurosoinnut näkyvät alaviivastolla ja numerot tarkoittavat aihion $e^{*}{ }^{*}$ IV asteita. 
on pieni terssi (6:5), ja sen heikkous näkyy myös g:n neurosoinnussa $\mathrm{Cm}$, jossa Esolu ei aktivoidu. Tahdissa 3 tapahtuu modulaatio, jossa C-solu on aktivoituneena E-solun rinnalla. Tapahtuu paluu aihioon $g^{\circ}{ }^{\circ} \mathrm{II}$, mutta paluuhetkeä ei voi täsmälleen määrittää. Voi vain todeta, että tämän laulun ominaispiirteenä on modaalinen lomittuminen, joka näkyy selkeästi nuottiesimerkin $6 \mathrm{C}$ tahdissa 3. Tässä tahdissa löytyy todiste myös edellä esitetylle oletukselle, jonka mukaan laulua hallitsee aihio *II. Tahdin sävelistä $c^{2}-e^{2}-c^{2}-h^{1}$ löytyy aihion g-*II "puuttuva" aste $3\left(e^{2}\right)$. Ollessaan lomittuneena kahteen aihioon sitä ei heti havaitse, mutta tässä se on.

Tahdissa 4 on yksityiskohta, joka vaatinee selityksen. Jos tahdin finalis on $g^{1}$, jonka tuottamassa neurosoinnussa $\mathrm{Cm}$ on aktivoituneena Es-solu, miten $e$-tutka voi tukea sitä? Tässä on ensin otettava käyttöön todellinen borduna $e^{1}$, joka tuottaa todellisen neurosoinnun Am. Yhteensattumaneuroni ei aktivoidu dissonanssien perusteella, joten kuulija ei ole tietoinen neuronaalisesta dissonanssista (jota kuulokeskus on täynnään). Sen sijaan tässä tapauksessa se aktivoituu, koska sävelen $g$ aktivoima G:3 = C-solu ja $e$-bordunan aktivoima E:5 = C-solu ovat harmonisessa suhteessa toisiinsa. Toisin sanoen $e^{1}$-borduna tukee laulettua $g^{1}$ :tä, mutta koska C-solu on kauttaaltaan vahvasti aktivoitu tahdeissa 3 ja 4, siitä tulee sitojasolu ja tätä kautta toonika. Tällöin finalis $g^{1}$ on nuottiesimerkissä $6 \mathrm{C}$ dominantti.

Samaisen nuottiesimerkin tahdissa 4 on yksityiskohta, johon on puuttuminen, koska sekin leimaa koko sävelmää. Kyse on dominantille asettuvasta päätössävelestä eli tilanteesta, jossa laulettu sävel on sama kuin tutkasävel. Tällöin kyseessä on priimi (1:1), jolloin tutka tukee laulettua säveltä vahvemmin kuin mikään muu suhde. Moodianalyysin kannalta laulettu sävel on dominantti, mutta kuulokeskuksen kannalta se saa hetkellisesti toonikan statuksen. Tällaista päätössävelenä toimivaa viidettä astetta kutsutaan arkiksi eli arkkitoonikaksi. Koska laulettua dominanttia tukee samalla dominantilla oleva tutka, arkki formalisoidaan siten, ettei sillä enää ole omaa dominanttia (vaikka se tietenkin aktivoi oman neurosointunsa). Siten arkkitoonikaa ei nimetä dominantin vaan sen itsensä mukaan. Sen symbolina on kreikkalainen omega $(\Omega)$. Jos arkkitoonikana on $g^{1}$, sen syntaktisena merkitsijänä on $g-\Omega$ eli g-omega. Nuottiesimerkin $6 \mathrm{C}$ päätössävel on aihion g-*II viides aste, ja samalla arkkitoonika.

Nuottiesimerkissä 5 kunkin arkkitoonikan juureen (viivaston alle) on lisätty pieni omega-kirjain. Niiden määrä on 11, joka on suhteellisen korkea näin lyhyessä melodiassa. Tällaisen toonikan viljelyn voi katsoa olevan merkittävä syntaktinen erityispiirre. Jos laulu perustuu yhden ainoan sävelen varaan, tämä sävel on G-ho- 


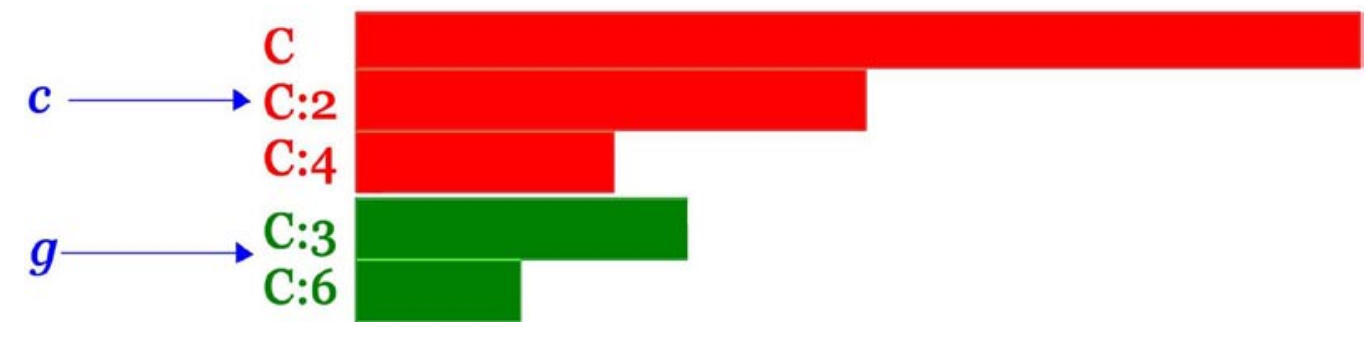

Kuva 8: Laulun päätössävelenä toonika $c$ tukee huomattavasti vahvemmin muistissa tai todellisesti soivaa toonikaa kuin dominantti $g$, jonka aktivoimat C-solut ovat G:3 ja G:6. Pinta-alaerot kuvaavat kuulijan tunnevahvuuksien eroa.

risontissa aina sävel $c^{2}$ symbolinaan c- $\Omega$. Nuottiesimerkistä 5 näkyy, että arkkitoonika on selkeästi painokas dominanttisävel, siis ennen kaikkea pitkään soiva finalis. Viides aste esiintyy tietenkin kaikissa lauluperinteissä, mutta useimmiten sen kesto on lyhytaikainen, eikä tällaisissa tilanteissa ole mieltä painottaa sen arkkiluonnetta, vaan se on aste muiden asteiden joukossa. Tilanne muuttuu, jos se esiintyy päätössävelenä. Musiikin kokeminen tapahtuu suhteessa muistissa olevaan tietoon. Jo kauan analyytikot ovat olleet sitä mieltä, että dominantille päättyvän sävelmän vaikutus on heikompi kuin toonikalle päättyvän melodian vaikutus. Tutkasävelteoria voi antaa tälle selityksen ilman tutkaa. Jos toonika on $c$, laulettuna se tukee maksimaalisesti Ckaistaa subharmonisilla soluillaan C, C:2, C:4, joista syntyvä vahva muistijälki yhtyy aiempiin jälkiin. Jos päätössävelenä lauletaan $g$, sen neurosointu $\mathrm{Cm}$ toki aktivoi Csolun, mutta heikommin, koska subharmoniset C-solut ovat G:3 ja G:6. Kuulija tulee tietoiseksi näistä ärsytystilan vahvuuseroista tunteella, että toonika on päätössävelenä vahvempi kuin dominantti (kuva 8).

Laulun Lagu dolanan pendhisil (nuottiesimerkki 5) ensimmäisellä rivillä tapahtuu melko yllättävä melodinen liike, joka näkyy nuottiesimerkissä 6D. Runon ensimmäiset säkeet ovat:

Pendisil, pendisil pendita leng ulengan,

jatan tiba lutung,

Ensimmäinen säe etenee kolmisävelisen markkerin $g^{-}{ }^{\circ} \mathrm{II}$ sävelillä. Neljännessä tahdissa sävelmäsäkeen päättää kesken viimeisen sanan (uleng-) markkerin kahdesti toistettu dominantti $g 1$, joka määrittyy arkkitoonikaksi $g-\Omega$. Sitten tulee melodiassa 


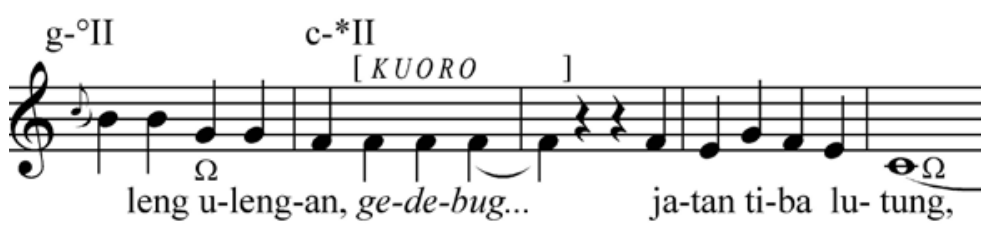

Nuottiesimerkki 6D. Tahdit 4-8 laulun Lagu dolanan pendhisil ensimmäiseltä riviltä. Mukana on kaksi todellista arkkitoonikaa, 1. tahdin $g^{1}$ ja viimeisen tahdin $c^{1}$.

välike, joka alkaa, kun solisti runosäkeen viimeisellä tavulla -an laulaa sävelen $f^{1}$. Siirtymä $f$-sävelelle on yllätys ja se on yksi laulun esteettisistä koukuista. Kysymys kuitenkin kuuluu: mitä tässä tapahtuu? Lapsijoukosta muodostunut kuoro yhtyy laulajaan vain kerran ja se tapahtuu tässä kohdassa sanalla gedebug, minkä jälkeen solisti jatkaa aihion c-*$^{*}$ II sävelillä ja päättää runo- ja melodiasäkeen (jatan tiba lutung, ) jälleen dominanttisävelelle, joka on $c$ - $\Omega$. Onko siis $f$-sävel arkkitoonika $f-\Omega$ ? Ensi alkuun ajattelin, että se on, mutta jaavalaisten laulajien kannalta näin ei ole, koska siirtymä $g:$ ltä f:lle on heille täysin tuttu. Jos kuoron laulamaa $f$-säveltä ei seuraisi siihen loogisesti suhteessa olevaa melodiakulkua, kyseessä olisi arkkitoonika. Koska seuraava laskeva motiivi kuitenkin etenee aihiossa $c^{-}{ }^{*} I I$, sävel $f$ onkin sen toonika. Tulkinta varmistuu laulun alimmalla rivillä, jossa sama toistuu, mutta ilman

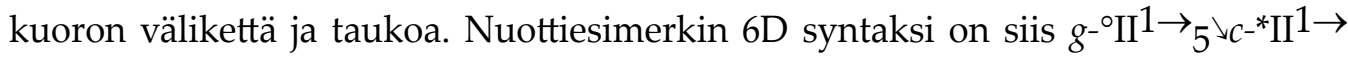
5 eli syntaktiset kuvaimet ovat liki identtiset; vain tutka laskee kvinttisiirrolla alas. Numerot $1 \rightarrow_{5}$ tarkoittavat, että melodia alkaa toonikalta ja päättyy dominantille. Laskeva nuoli $\downarrow$ osoittaa tutkan liikesuunnan. Tästä paljastuu myös se, että syntaksin kuvaimille riittää, että päätössävelenä oleva dominantti ilmaistaan alaindeksillä 5 .

Lagu dolanan pendhisil avautuu varhaisheksatonaalisen aihion markkerilla g- $^{\circ} \mathrm{II}_{5}$ ja pitkän laulun päättää kvinttiä alempana olevan samaisen aihion dominanttisävel: $\mathrm{c}^{*}{ }^{-} \mathrm{I}^{1} \rightarrow_{5}$. Melodianmuodostusta luonnehtii jatkuva lomikointi: edellisen aihion viimeinen sävel toimii seuraavan aihion aloitussävelenä. Täten aihioiden välissä ei ole selkeää rajaa. Esimerkiksi tahdin 12 toonika $c^{2}$ jatkuu seuraavassa tahdissa, mutta muuntuu statukseltaan dominantiksi, tarkemmin sanottuna sen yläoktaaviksi. Koska dominantti on melodialiikkeen korkein sävel, aihio c-*II on rakenteeltaan riippuva. Tämä syntaktinen piirre ilmaistaan yläindeksillä $\mathrm{P}$, joka tulee latinan sanasta pendeô 'riippua'. Näin tahdin 13 syntaksina voisi olla c- ${ }^{*} \mathrm{PII}$, mutta kun melodialiike pohjautuu markkerin asteille 5-1-6-1, markkerin symboli ${ }^{\circ}$ korvaa tähden: $\mathrm{c}^{-}{ }^{\circ} \mathrm{PII}$. Sama 
voidaan soveltaa tahteihin 20-21, jonka aihio laskeutuu oktaavilla suhteessa rivin alkupuolen samaan aihioon. Lomitus koskee myös runonkäsittelyä, jolloin transpositio saattaa tapahtua sanan yhden tavun kohdalla kuten näkyy sanoissa uleng lan tai kong tai sapulalre (tahdit 4-5; 12-13; 21-22).

Syntaksin yleiskaavana on leikitellä moodin *II markkerilla, mutta tästä on yksi poikkeus, joka on tahdeissa 24-27: tapahtuu hetkellinen modulaatio käänteiseen aihioon $\mathrm{e}^{*} \mathrm{iV}$, mutta tämäkään ei kauan pysy, sillä melodiasäe päättyy taas aihion *II markkeriin. Modulaatio käy täysin yksiin runon sisällön kanssa. Säkeessä Nala Jaya bang bub: tute neljännen moodin aihio vaihtuu viimeisen sanan tute aikana (ja siis kaksoispisteen jälkeen) moodin g-* II markkeriksi. Kokonaisuudessaan tahdeissa 24-28 etenevä liike on c-*II - $\mathrm{e}^{*} \mathrm{iV}-\mathrm{g}$ - ${ }^{\circ}$ II. Nousevaa tutkasävelsarjaa $c^{1}-e^{1}-g{ }^{1}$ voidaan tuskin pitää tyystin sattumanvaraisena, koska tämä tutkasarja vastaa $c$-sävelen ääneksiä 4-5-6. Kun keskeisimmät liikkeet asetetaan järjestykseen, laulun syntaksi voidaan kirjoittaa. Vaikka kyse on lastenlaulusta, syntaksi on monimutkainen ja siihen palataan kirjoituksen lopulla.

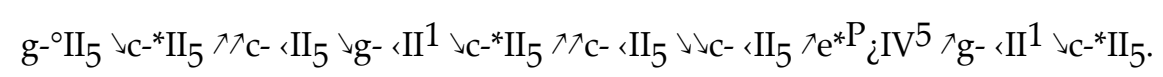

Sarjan ensimmäinen numero 5 osoittaa aloitussävelen asteen muiden numeroiden osoittaessa kunkin osion päätössävelen asteen. Syntaksissa on viisi keskeistä piirrettä, jotka herättävät huomion. Ensinnäkin varhaisheksatonaalinen markkeri ${ }^{\circ}$ on poikkeuksellisen vahvasti läsnä. Keskeinen aihio on *II, joka kerran muuntuu *IV:ksi. Kolmantena piirteenä on viidennen asteen toimiminen päätössävelenä. Piirre on leimallinen ja se siis tarkoittaa hienotasolla arkkitoonikan keskeistä asemaa syntaksissa. Neljäntenä piirteenä ovat tutkasävelen siirtointervallit, sillä niillä on arvattavasti - siis testattavan hypoteesin arvoinen - merkitys universaalitutkimuksessa: tutka liikkuu ennen kaikkea kvintillä alaspäin, oktaavilla ylöspäin ( $\gg)$ ja oktaavilla alaspäin $(\triangleleft \downarrow)$.

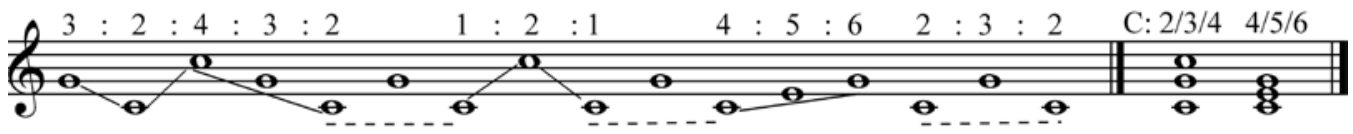

Nuottiesimerkki 6E. Laulun Lagu dolanan pendhisil pohjalla olevien tutkasävelten sarja. Jos sarja soitettaisiin, sen jokainen sävel pitäisi C-solut ärsytystilassa. Ne järjestyvät keskenään kuten c:n äänekset 2:3:4:5:6. 
Tutkasävellinja on omalaatuinen ja sillä lienee laajemman vertailuaineiston kannalta tärkeä merkitys (nuottiesimerkki 6E). Ensinnäkin tutkat $c^{1}-g^{1}-c^{2}$ ovat suhteessa toisiinsa kuten C:n äänekset 2, 3, ja 4. Jos melodia rakentuu vain toonikasta ja dominantista, tällaista kaksisävelikköä kutsun peruspariksi, jolle rakentuva sävelmä pitää toonikaa vastaavan solun kaiken aikaa aktiivitilassa. Sävelet saattavat laajeta kolmikoksi sen mukaan onko korkein sävel toonika vai dominantti. Tämän laulun tutkat asettuvat siten, että keskellä on dominantti (ks. nuottiesimerkki 6E, tahti 2). Syntaksia hallitsevaa tutkasävelsarjaa luonnehtii siis dominanttikeskinen peruspari, mikä havainto on tärkeä syntakseja typologisoivan tutkimuksen kannalta. Tämä katkeaa vain kohdassa, jossa melodiaan ilmaantuu mollimainen aihio $\mathrm{e}^{* \mathrm{P}}$ ¿IV $^{5}$. Tutka nousee sävelillä $c-e-g$, joka liike vastaa $c$ :n ääneksiä 4-5-6. Melodia rakentuu kaiken kaikkiaan tukevasti toisiinsa suhteutuvien tutkasävelten varaan eli kuten $c$-sävelen äänekset 1-2-3-4-5-6. Tästä huolimatta melodia on syntaksiltaan niin monimutkainen, että eurooppalaiselta vaatii aikaa oppia se ulkoa.

\section{Kupu kuwé (Kupu kuning)}

Aluksi laulun syntaksin määrittäminen näytti toivottomalta, koska kaiken aikaa tuntui olevan kaksi vaihtoehtoista ratkaisua. Ongelman aiheutti aloituskuvio $h^{1} 1_{-g} 1_{-h} 1_{-}$ $c^{1}$, jonka aktivoimat neurosoinnut Em-Cm-Em-Fm pitävät pääosin G-kaistat ärsytystilassa. Näin G:n pitäisi olla neksus ja toonika:
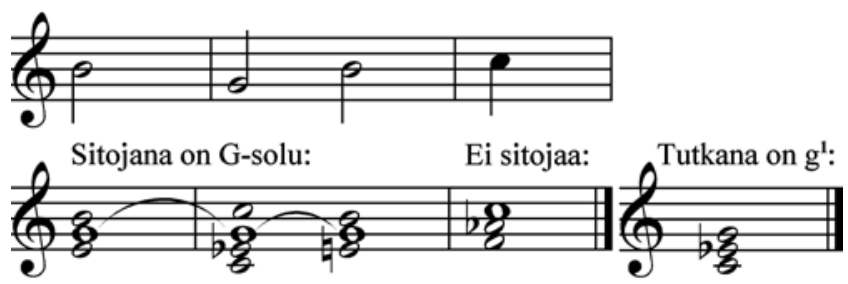

Nuottiesimerkki 7A. Kupu kuwé aloituskuvio (yläviivasto) ja sen soluvasteet neurosointuina (alaviivasto). 
Tämän kaltainen aloituskuvio voikin opettaa analyytikolle useita seikkoja:

1) Kuvion perustana on delta-markkeri $g^{\circ}{ }^{\circ} \delta$ ja melodia liikkuu sen asteilla 6-5-6-1.

2) Tällainen aloitus on ominainen Jaavalle. Muualta en ole vastaavaa tässä määrin kohdannut.

3) Tahtien 1 and 2 aikana sitojana on G-solu. 3. tahdissa ilmaantuu toonika $c^{2}$, joka aktivoi neurosoinnun Fm.

4) Kuvion tutkasävelenä on $g 1$, jonka neurosoinnun Cm kaistat C, Es ja G tukevat kutakin laulettua säveltä.

5) Tahtien 1 and 2 alleeli g- $\delta$ on käänteinen, koska vahvasti painotettu G-solukaista on sekä neksus ja toonika että tutkasävel. Kolmannen tahdin $c^{2}$ on kuin arkkitoonika. Mikrotasolla avauskuvion syntaksi tulisi siis kirjoittaa g- $i^{\delta}{ }_{6 \rightarrow 6}{ }^{\top} \mathrm{c}-\Omega$, mutta näin monimutkainen merkintä on tarpeetonta. Riittää, kun muistetaan, että deltamarkkeri on vahvasti käänteinen asteiden 5 ja 6 vuoksi. Nuottiesimerkin 7A avausku-

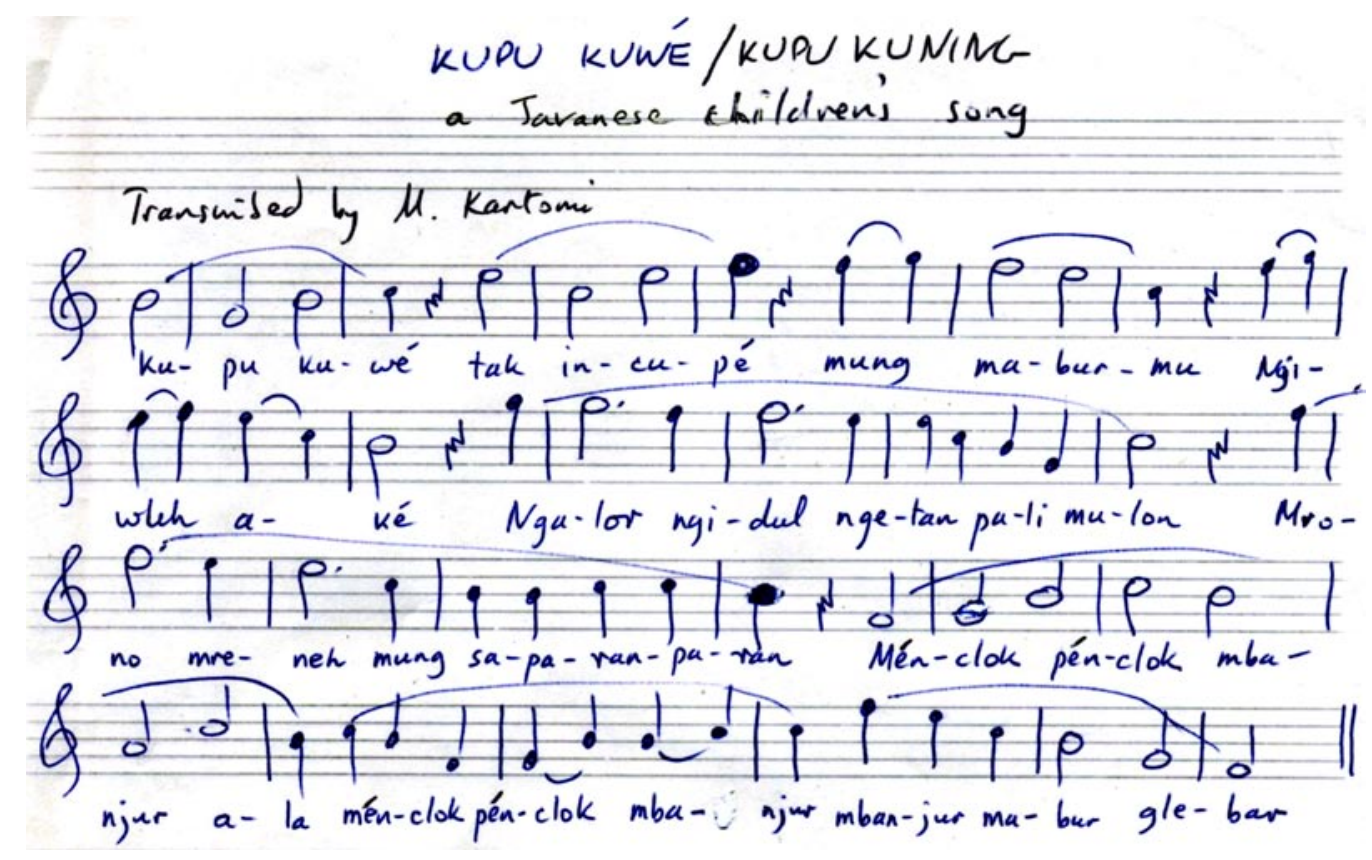

Nuottiesimerkki 7B. Kupu kuwén alkuperäinen käsikirjoitus Margaret Kartomin nuotintamana. Se on jo valmiiksi G-horisontissa, jolloin $g^{1}$ on aloittava dominanttisävel ja $c^{2}$ on toonika. Paikallisen määritteen mukaan laulun moodina on heptatoninen $f$-pohjainen pelog. 
vion voi redusoida universaaliasuun $\mathrm{g}^{\circ} \delta_{6} \rightarrow 1$ eli se kääntyy luonnolliseksi motiivin lopussa. Sama toistuu kvarttia korkeammalla $\left(\mathrm{c}^{\circ} \delta_{6} \rightarrow 1\right)$.

Runon sisältönä on Margaret Kartomin mukaan "Keltainen perhonen, lennä pois tai joudut kiinni. Lehahda kukasta kukkaan." Laulu siis edustaa välinettä, jolla lapset kommunikoivat ympäröivän luonnon kanssa - vähän samaan tapaan kuin meillä lennätetään leppäkerttua ja pyydetään etanaa näyttämään sarvensa.

Kири kuwé pohjaa syntaksiltaan selkeästi samoihin elementteihin kuin edellä ollut Lagu dolanan pendhisil. Muun muassa modaalinen lomittamistekniikka muokkaa vahvasti melodianmuodostusta. Jos nuottiesimerkin 8 alinta riviä tarkataan lähemmin, esille saadaan tulos, joka näkyy nuottiesimerkissä 9. Aihioiden aktivoitumiskohdat näkyvät kuvasta 8, mutta niiden valmistelu tapahtuu jo ennen. Tutkasävelen yhtenä keskeisenä ideana on tarkastella, mikä sävel kykenee kauimmin tukemaan laulettuja säveliä. Nuottiesimerkin 9 tahdeissa 5 ja 6 vaikuttaa aihio c-*II, mutta melodiankulku nuottiesimerkissä 8 paljastaa, että se aktivoituu vain 6 . tahdissa sävelen $f^{2}$ aikana. Sen kahta puolta aktiivisena tutkana on $g$. Nuottiesimerkin 9 päätössävel $f$ on kiinnostava. Se toki esiintyy aihion c-*II toonikana, mutta juuri tässä kontekstissa sitä on vaikea pitää tuossa statuksessa. Sen sijaan sen asema käy selväksi, jos se määritetään arkkitoonikaksi, joka on aihion $\mathrm{f}^{*}{ }^{*} \mathrm{VI}$ dominantti. Tämä aihio $\mathrm{f}_{-}{ }^{*} \mathrm{VI}\left(f^{1}-a^{1}{ }_{-}\right.$ $\left.h^{1}-c^{2}-d^{2}\right)$ ei esiinny muissa sävelmissä, mutta sen ainekset esiintyivät Kupu kuwén alimmalla viivastolla jo aiemmin, joskin niin mielenkiintoisesti lomittuneina, ettei niitä huomaa, vaikka 4. tahdissa tapahtuvan tritonus-pudotuksen $h^{1}-f^{1}$ olisi pitänyt herättää huomio. Kyseessä on lasku tämän aihion toonikalta $h^{1}$ sen dominantille

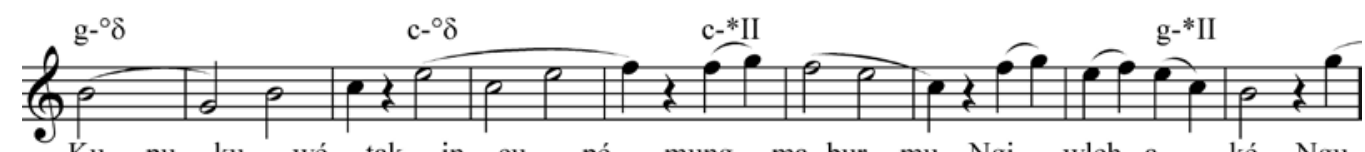

Ku - pu ku - wé tak in - cu - pé mung ma -bur - mu. Ngi - wleh a - ké. Ngu-

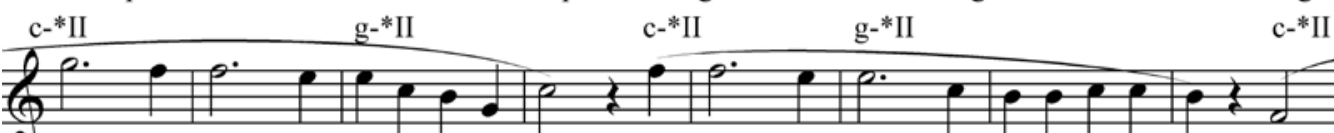

- lor ngi-dul nge-tan pa-li mu - lon. Mro-no mre-neh mung sa-pa-ran-pa-ran. Mén-

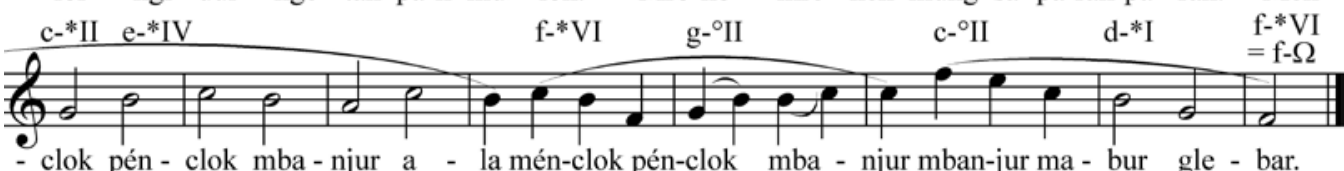

Nuottiesimerkki 8. Kupu kuwé. Symbolit c-II ja g-II voi korvata c-*II:lla ja g-*II:lla. 
$f^{1}$. Tulkintani on, että alimman viivaston 4 . tahdin sävelet $c^{2}-h^{1}-f^{1}$ ennakoivat melodian päätössäveltä $f^{1}$, joka ei kuitenkaan jatku mihinkään, vaan on sävelmän painollinen loppu. Tutkasävelteorian mukaan dominantille päättyvä sävelmä on aina dominanttia kaipaamaton arkkitoonika, joten tässä tapauksessa kyseessä on aihion f-*VI dominantti eli arkki f- $\Omega$. Lomittuminen on siinä määrin tiheää, ettei samaa voi kuvitella tapaavansa Euroopassa. Kyseessä on jaavalaisen tradition erikoisuus.

Suhteessa nuottiesimerkkiin 9, nuottiesimerkki 8 paljastaa mielenkiintoisia yksityiskohtia. Ensinnäkin aloituskuvio g- ${ }^{\circ} \delta_{6} \rightarrow 1$ toistuu tahdeissa $3-5$ kvarttia korkeammalla (c- ${ }^{\circ} \delta_{6} \rightarrow 1$ ), mutta tahdeissa 5-8 laulaja laajentaa sitä 2. asteella $g^{2}$. Täten kolmisävelinen markkeri muuttuu nelisäveliseksi alleeliksi, jolloin symboli ${ }^{\circ}$ katoaa näiden tahtien syntaksikuvaimesta: c- $\delta 1 \rightarrow_{5}$. Sävel $d^{2}$ ei voi olla mukana delta-alleelin asteiden 5 ja $6\left(c^{2}\right.$ ja $\left.e^{2}\right)$ välissä. Tämä saattaa olla syynä siihen, ettei säveltä $d^{2}$ lauleta myöskään alleelin g- $\delta$ osana. Keskimmäisellä viivastolla sävel $e^{2}$ esiintyy alleelin $\mathrm{g}-\delta$ yhteydessä. Tuo sävel ei kuitenkaan kuulu delta-alleeliin vaan sen laajentumaan eli aihion g-*II asteena 3. Sama toistuu laulun lopussa (ks. nuottiesimerkki 8: -jur mabur gle-).

Ei siis näytä olevan syytä epäillä, että tähän asti delta-alleeliksi g- $\delta$ määritetty aines voidaan määrittää aihion g-* ${ }^{*} I$ osaksi. Näiden kahden erottelu valaisee mikrotasolla melodianmuodostuksen (tai pelogin) periaatteita, mutta pelkistetyssä syntaksikuvauksessa se on tarpeeton. Sävel $a^{2}$ ei esiinny kertaakaan ja $a^{1}$ yhden kerran. Sävelen $a^{1}$ systemaattinen puuttuminen selittyy sillä, ettei sitä voi olla aihion g-* ${ }^{*}$ asteiden 5 ja 6 välissä. Täten voidaan todeta, että alleelit $g-\delta$ ja c- $\delta$ edustavat yhtä ja samaa aihiota *II, joka edellisen laulun tapaan siirtyilee dominanttien $g^{1}$ ja $c^{2}$ varassa. Tästä huolimatta melodian syntaksille on aivan leimallista, että se etenee kolmisävelisten markkereiden varassa, jolloin syntaksin ainekset ovat g-II ja c-II - aivan kuten edellisessä laulussa.

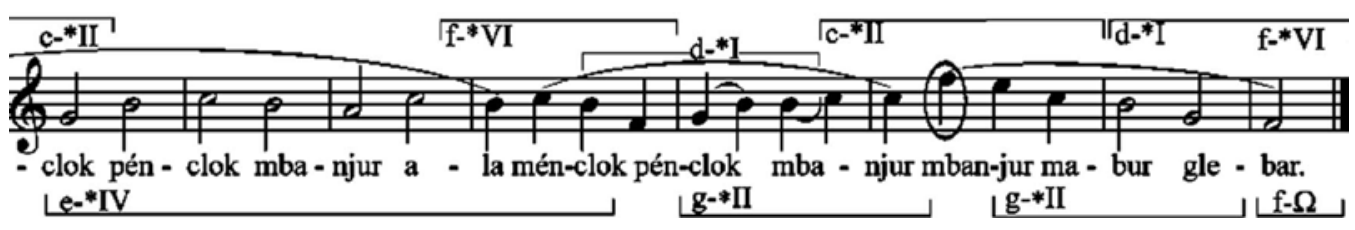

Nuottiesimerkki 9. Aihioiden lomittuminen Kupu kuwén alimmalla viivastolla. 


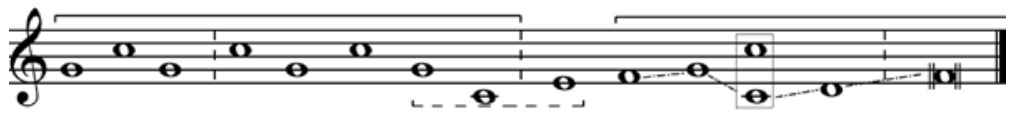

Nuottiesimerkki 10. Laulua Kupu kuwé luonnehtivien tutkasävelten sarja. Kolme ensitahtia tarkoittaa kolmea viivastoa, mutta viimeinen tahti liittyy vain päätössäveleen.

Laulun kokonaisrakenne näkyy tutkasävelten sarjana nuottiesimerkissä 10. Kahta ylintä viivastoa hallitsee aihio *II, joka vuorottelee $c$ :llä ja g:llä. Täten tämänkin laulun pääosa pohjautuu perusparille $c^{2}-g^{1}$ ja kerran dominanttikeskiselle perusparille. Peruspari ilmaantuu kolmannellakin viivastolla, mutta ylipäätään siinä syntaksi muuttuu vahvasti, koska tapahtuu modulaatio duurimaisesta aihiosta c*II mollimaiselle aihiolle e-* IV. Modulaatiota edeltää tutkasävelliike $g^{1} c^{1}{ }^{1} e^{1}$, joka on yhtä harmoninen kuin peruspari, koska se vastaa C:n ääneksiä 6:4:5. Edellisen laulun lailla tutkasävelet suhteutuvat toisiinsa kuten c:n äänekset 1-2-3-4-5-6. Päätössäveltä $f^{1}$ lukuun ottamatta ketju on ihmeellisen luonnollinen. Kolmannen rivin aikana tapahtuu siis aihion f-*VI lyhyt valmistelu ja se myös yllättävästi päättää melodian. Tämä aihio on erikoinen $\mathrm{mm}$. sen vuoksi, että dominantin ja toonikan välillä on tritonussuhde ja sen asteet 5-6-2 pitävät tutkaa vastaavan solun aktiivitilassa ja sen 3. astekin tukee tutkan neurosointua. Tämä tarkoittaa, että aihio on luonnostaan käänteinen: sillä ei ole luonnollista olomuotoa.

Lisäpiirre, joka yhdistää edellisen ja tämän laulun, näkyy alimman viivaston tahdeissa 1-4, joissa häivähtää luonnollisen a-mollin varhaisheksatonaalinen aihio e*IV. Lomittuminen on niin vahvaa, ettei voi täsmälleen sanoa, mistä se alkaa ja mihin päättyy. Kun laulussa Lagu dolanan pendhisil toonika $a^{1}$ oli mahdollista saada esille vain teoreettisesti, tässä se lauletaan selkeästi esille - tosin yhden ainoan kerran. Sävelkulku $h^{1}-c^{2}-h^{1}-A^{1}-c^{2}-h^{1}-c^{2}$ koostuu aihion e-* IV asteista 3-2-1, joita kaikkia tutkasävel $e^{1}$ tukee neurosoinnullaan Am (A-C-E).

Erojakin laulujen välillä on. Lagu dolanan pendhisille keskeinen piirre oli tutkasävelten välinen laskeva kvintti $g^{1}-c^{1}$, joka Kupu kuwéssa on kääntynyt nousevaksi kvartiksi $g^{1}-c^{2}$. Ehkä rajuin ero on kuitenkin päätössävelen $f^{1}$ statuksessa, joka laulussa Kupu kuwé ei ole aihion c-*II toonika. Tämän lastenlaulun päätössävel on eurooppalaisen syntaksin omaksuneelle kuulokokemuksena outo, mutta Margaret Kartomi kokee sen ilmeisen samoin kuin keskijaavalaiset: laulu on kaunis. 


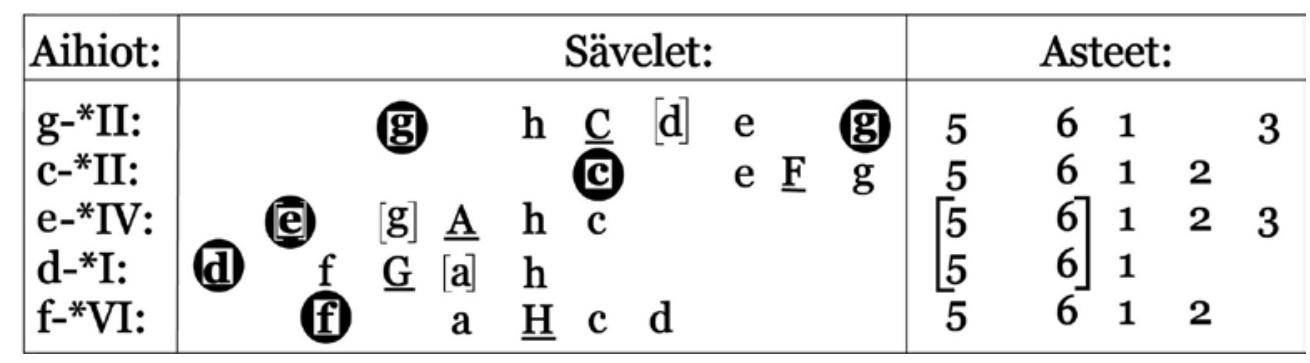

Kuva 9.Kupu kuwé- laulussa vuorottelevat aihiot. Niiden asteikot ilmaistaan nousevina ja kunkin toonika ilmaistaan alleviivaten suurella kirjaimella. Aihioiden tutkasävelet (kaikissa sama kuin dominantti) on paksunnettu ja ympyröity. Hakasuluissa olevia asteita ei lauleta. Oikealla näkyy, mistä sävelasteista melodia kulloinkin rakentuu.

Nuottiesimerkissä 8 esiintyvät viisi varhaisheksatonaalista aihiota näkyvät kuvassa 9. Tällaista tulosta ei saa esille sen kummemmin eurooppalaisista kuin afrikkalaisistakaan syntakseista - ei ainakaan tutkimuksen nykytiedon valossa. Lopuksi voidaan kirjoittaa Kupu kuwén koko syntaksi, joka on looginen mutta monimutkainen. Nuottiesimerkin 8 aloittamat delta-alleelin markkerit $\mathrm{g}{ }^{\circ} \delta$ ja $\mathrm{c}^{\circ}{ }^{\circ} \delta$ on muutettu tässä aihioiksi g- ${ }^{\circ} I I$ ja c- ${ }^{\circ} I I$.

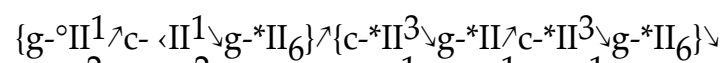

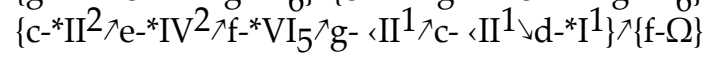

\section{Gajah}

Toisin kuin edelliset tämä melodia etenee pentatonaalisen slendron sävelillä (nuottiesimerkki 11). Professori Kartomi nuotinsi sen Hidris Kartomin esityksen mukaisesti toukokuussa 2010 ja toimitti myös runon käännöksen, joka suomennettuna on:

Elefantti, elefantti, kerronpa nyt sinulle:

Vinot ovat silmäsi ja suuret ovat korvasi

Pikkuhäntäs' kiikkuu ja jalkas' on tukevat bambunvarret

Peppusikin vaappuu kuin lihavalla tytöllä. 


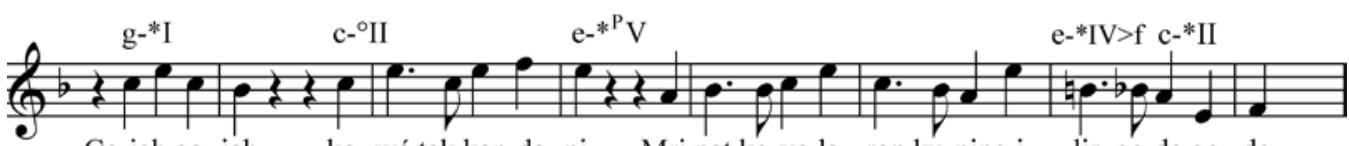

Ga-jah ga- jah ko- wé tak kan-da- ni, Mri pat ko-yo la - ron ku-ping i - lir ge-de ge - de,

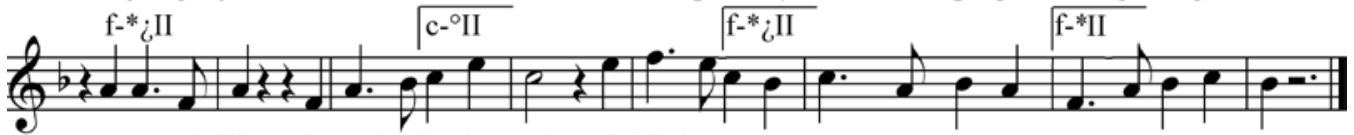

Bun-tut ci- lik da-sar ko-bat ka - pit, Si- kil ko-yo bum-bung mung mla-ku mu mè-gat mè - got

Nuottiesimerkki 11. Keskijaavalainen lastenlaulu Gajah 'Elefantti' Margaret Kartomin nuotintamana.

Syntaksi sisältää lukuisia yhtäläisyyksiä edellisiin. Yhtenä on tutkasävelten välisten suhteiden täysi luonnonmukaisuus yläviivastolla: $g^{1}-c^{2}-e^{2}-c^{1}$ vastaa $c: n$ ääneksiä 3-4-5-2 ja C-solun subharmonioita C:3-C:4-C:5-C:2. Alaviivaston tutkasarja $f^{1}-c^{2}-f^{1}$ taas vastaa C:n subharmonioita C:3-C:2-C:3 (nuottiesimerkki 12).

Tutkat $f^{1}$ ja $c^{2}$ aktivoivat neurosoinnut Fm ja Bm. Näin F-solu pysyy kaiken aikaa ärsytystilassa, jolloin se on neksus ja sävelellinen toonika. Kun tutkana on $f^{1}$, aihiona on käänteinen $\mathrm{f}-{ }^{*} i$ II $\left(f^{1}-a^{1}-b b^{1}-c^{2}-e^{2}\right)$ ja kun tutkana on $c^{2}$, aihiona on sen luonnollisen aihion markkeri c- ${ }^{\circ} \mathrm{II}\left(c^{2}-e^{2}-f^{2}\right)$. Kuitenkin alaviivaston kahdessa viimeisessä tahdissa lauletut sävelet $f$ and $b$ aktivoivat B-solun, jolloin siitä tulee lopun neksus ja sävelestä $b^{1}$ tulee toonika. Näin käänteinen $\mathrm{f}^{*}{ }^{*}$ ¿I kiepahtaa laulun lopussa luonnolliseksi (f-* II). Kummallakin on sama asteikko, mutta aktivoituneiden solujen ja sävelasteiden väliset suhteet ovat niissä erilaiset.

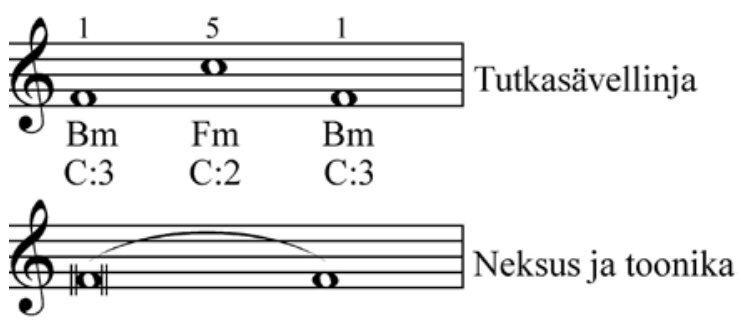

Nuottiesimerkki 12: Gajahin alaviivaston melodinen ydin. Vaikka aihiot muuttuvat, ärsytystilassa pysyttelevät F-solut (neksus) sitovat kaikki liikkeet yhteen. Täten toonikana on sävel $f$. 


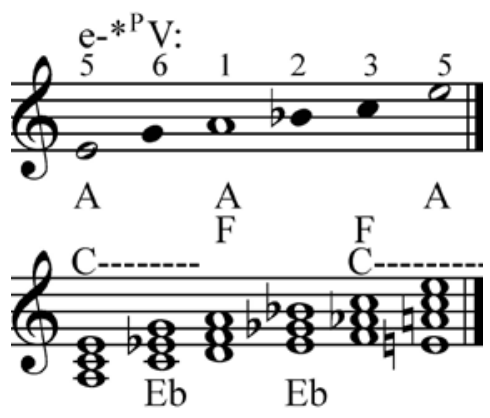

Nuottiesimerkki 13: Aihion e-*V rakenne ja soluvasteet neurosointuina. Kirjaimet A, C, F ja Es nuottien alla vastaavat sävelten vahvimmin aktivoimia kuulosoluja.

Laulussa on neljä säettä eli kummallakin viivastolla on yksi säepari, joiden syntaksit ovat selkeästi erilaiset. Yläviivastoa hallitsee sarja $\mathrm{g}^{*}{ }^{*} \mathrm{I}^{1}{ }_{\mathrm{C}}-\left\langle\mathrm{II}^{3}{ } \mathrm{e}^{*} \mathrm{P}_{\mathrm{V}}{ }^{5} \downarrow \mathrm{e}-\right.$ $* \mathrm{P}^{5}{ }^{5} \mathrm{~g}-{ }^{*} \mathrm{II}^{3}{ }_{{ }_{\mathrm{C}}-{ }^{*} \mathrm{II}}{ }^{1}$ eli tutkan sävelvuo liikkuu ikään kuin C-duurikolmisoinnun sävelillä. Sama piirre ilmeni kahdessa edellisessä laulussa. Alaviivaston syntaksi taas kieppuu f:n ja c:n varassa: $\mathrm{f}^{*}{ }_{i} \mathrm{II}_{6}{ }^{\top} \mathrm{c}^{-}-\left\langle\mathrm{II}_{5} \backslash \mathrm{f}-{ }^{*} i \mathrm{II}_{5} \rightarrow \mathrm{f}^{-}{ }^{*} \mathrm{II}^{1}\right.$.

Moodi V on monimutkaisuudestaan huolimatta universaali. Kuitenkin $b$-säveltä lukuun ottamatta sen asteita tukee yksi sävel, $e^{1}$ (> neurosointu Am = A-C-E), joka tukee myös toonikaa $a^{1}$. Tämä antaa avaimet tulkita viides moodi. Melodian kuluessa se koostuu kahdesta vuorottelevasta elementistä, joista ensimmäisessä ovat sävelet $e^{1}-g^{1}-A^{1}$, jotka ovat kolmeen eri moodiin johtavan alfa-alleelinmarkkerin asteet 5-6-1. Sen syntaktisena symbolina tässä on $\mathrm{e}^{-} \alpha$, ja tämä alleeli voi johtaa aihioihin e- ${ }^{*}$, e- IVja e-*V. Viidennen moodin loppuna sävelet $b^{1}, c^{2}$ ja $e^{2}$ ovat kuten aihion g-* I asteet 6-1-3, ja siinähän $c^{2}$ on toonika ja $g^{1}$ on dominantti. Kun aihio e-*Vtulkitaan näin, havaitaan, että tätä modaliteettia voi kuvata syntaktisella prosessilla e- ${ }^{\circ} \alpha$ $\leftrightarrow$ g- ${ }^{*}$ I, mitä nuottiesimerkki 14 havainnollistaa. 


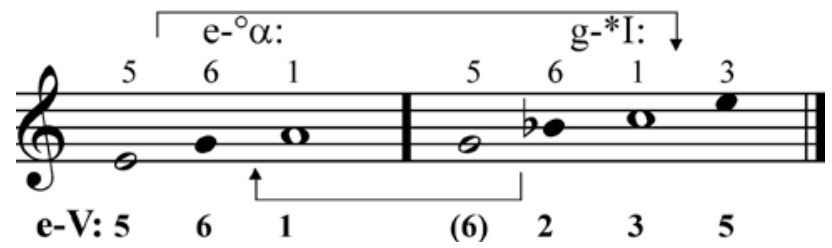

Nuottiesimerkki 14: Aihio e-*V prosessina. Ensitahdissa on alfa-alleelin markkeri $\mathrm{e}^{\circ} \alpha$, joka vuorottelee toisessa tahdissa olevan aihion g-*$^{*} \mathrm{I}$ kanssa. Näiden asteet näkyvät viivaston yläpuolella. Tuloksena on pentatonaalinen moodi e-V, jonka asteet näkyvät viivaston alapuolella. Jotta melodia olisi G-horisontissa, tässä näkyvä aines on nostettava pienellä terssillä ylös: $g^{1}-b^{1}-c^{2}-d e s^{2}-e s^{2}-g^{2}$.

Gajah-laulussa moodia V käsitellään mielenkiintoisella tavalla. Laulaja siirtyy siihen lomittamalla: ylemmän viivaston tahdissa 4 oleva sävel $e^{2}$ on edellä olevan c-pohjaisen c- ${ }^{\circ}$ II -aihion aste 6 . Kuitenkin kuudennen asteen käyttö finaliksena ei ole motivoitu, koska se ei ole vahvassa suhteessa toonikaan eikä dominanttiin. Onkin oletettavissa, että 4 . tahdin aloittavan sävelen $e^{2}$ tehtävä on ennen kaikkea merkitä aihion $\mathrm{e}^{*} \mathrm{~V}$ dominanttisävel kohdalleen. Näin siis laulaja lomittaa tuon sävelen aikana aihiot $\mathrm{c}^{\circ} \mathrm{II}$ ja e- ${ }^{*} \mathrm{~V}$, vetää henkeä ja aloittaa uuden melodiasäkeen 4 . tahdin lopussa laulamalla aihion e-*V toonikan $\left(a^{1}\right)$. Sävel $e^{2}$ toistuu vielä kahdesti, kun taas $e^{1}$ puuttuu. Tämän vuoksi aihio on rakenteeltaan riippuva e- $* P_{V}$. Ylärivillä esiintyvä melodinen liike $c^{2}-e^{2}$ on ja pysyy, mutta sävelten suhteet muihin säveliin muuttuvat kaiken aikaa, koska ne ovat aihion c- ${ }^{\circ}$ II asteet 5-6, aihion g-* I asteet 1-3 ja aihion e- ${ }^{* P}$ asteet 3-5. Sävelten keskinäisten suhteiden vaihteluilla täytyy olla vaikutus kuulijan kokemukseen.

Ylemmän viivaston päättävä liike $e^{2}-h^{1}-b^{1}-a^{1}$ (ilir gede) on kaikin puolin epätavallinen. Menemättä yksityiskohtiin, liike $h^{1}-b^{1}$ yksinkertaistetaan $b^{1}: k s i$. Todellisen kuvion tehtävänä lienee päättää ensimmäinen säepari ja valmistaa kuulija modaalisesti aivan toisenlaiseen säepariin, joka etenee ennen kaikkea tutkasävelen $f$ suhteen. Täten laulun syntaksina on:

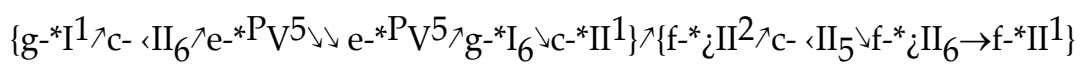




\section{Syntaksin rakentumisen periaatteet}

Artikkelin päämääränä ei ole selvitellä, miten pelog and slendro suhteutuvat tutkasävelteorian avulla saataviin päätelmiin. Tehtävänä on ollut pyrkiä ymmärtämään syntaksien rakentumisen periaatteita sekä sitä, miksi melodianmuodostus Jaavalla on kovin toisenlaista kuin vaikkapa Afrikassa ja Euroopassa.

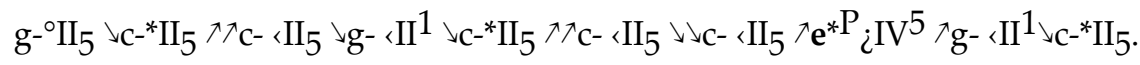

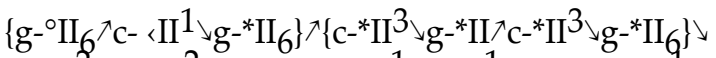

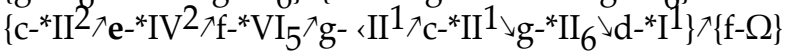

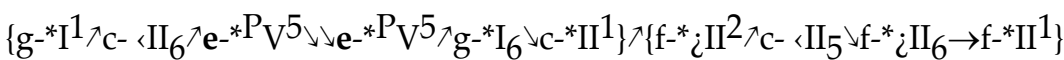

Kaikki kolme syntaksia on sovitettu alkamaan G-horisontissa. Vaikka lauluja on vain kolme ja vaikka ne ovat paikallisia, niissä on syntaktisesti varsin korostuneita erikoispiirteitä, joilla saattaa olla paljon Keski-Jaavaa laajempi maantieteellinen levikki. Ensimmäisenä piirteenä nousee esiin aihioiden * ${ }^{*}$ ja ${ }^{*} \mathrm{I}$ ja niiden alleelien (delta ja gamma) keskeinen asema. Kolmessa syntaksiketjussa on yhteensä 10+15+9=34 elementtiä (kuten g- ${ }^{\circ} I I$ ja e-*PV). Niistä 26 (76 \%) edustaa aihiota *II tutkasävelinään $g$ ja $c$. Aihion *I määrä on kolme ( $9 \%$ ) tutkasävelinään $g$ and $d$. Aihiot e-* IV ja f- ${ }^{*} \mathrm{VI}$ esiintyvät kahdesti (kummankin osuus on $6 \%$ ) ja e-*V kerran (3\%). Kaiken kaikkiaan siis varhaisheksatonaalisten aihioiden *II ja *I osuus kolmessa syntaksissa on $85 \%$. Oireellisesti ne näyttävät hallitsevan myös Australian aboriginaalien syntakseja liittyneinä ainakin aihioihin ${ }^{*} \mathrm{IV}$ ja ${ }^{*} \mathrm{~V}$. Jaavalaiseen tapaan aihio *III on Australiassakin joko varsin harvinainen tai puuttuu tyystin kuten näissä kolmessa laulussa. Kiintoisa yksityiskohta näkyy, kun melodiat alkavat G-horisontissa. Kun niihin ilmaantuu aihioille *II ja ${ }^{*}$ I kontrastiivinen aines $\left({ }^{*} \mathrm{IV}\right.$ ja $\left.{ }^{*} \mathrm{~V}\right)$, se tapahtuu E-horisontissa, minkä vuoksi $e$-tutkat on maalattu punaisiksi oheisessa luettelossa. Selitys kontrastiivisuuden liittymisestä juuri aihioihin ${ }^{*} \mathrm{IV}$ ja ${ }^{*} \mathrm{~V}$ on siinä, että kummankin markkerina on sama alfa-alleeli $e^{1}-g^{1}-a^{1}$, mutta jos jatkossa 2 . asteena on $b^{1}$, tuloksena on e-V, vaan jos 2. asteena on $h^{1}$, tuloksena on e-IV.

Toinen keskeinen piirre on markkereiden korostunut asema. Niiden määrä redusoiduissakin syntaksikuvaimissa on 13 eli noin $40 \%$ ja kaikki liittyvät aihioon *II, joka on myös läntisen duurin aihio. Todellinen määrä on vieläkin suurempi, sillä monin paikoin markkeriin c- ${ }^{\circ} I I\left(c^{1}-e^{1}-f^{1}\right)$ liittyy sävel $g^{1}$, jolloin aineksen kuvaimeksi muuttuu c-*II. Toisin sanoen varhaisheksatonaalisen toisen aihion markkeri 
leimaa poikkeuksellisen voimakkaasti keskijaavalaista syntaksia. Tämä voidaan siis esittää varmennusta vaativana hypoteesina.

Seuraava epätavallinen piirre on tutkasävelen liike laajoina kvintti- ja oktaaviintervalleina. Ylöspäinen kvintti $\left(g^{1}-d^{2} ; f^{1}-c\right)$ esiintyy kahdesti $(6 \%)$ ja sama alaspäin $\left(g^{1}-c^{1} ; c^{2}-f^{1}\right)$ toistuu kuudesti (19\%). Kahdesti (6\%) tutka siirtyy oktaavilla ylös $\left(c^{1}-c^{2}\right)$ ja alas $\left(c^{2}-c^{1} ; e^{2}-e^{1}: 6 \%\right)$. Globaalisti tavallinen kvarttisiirtymä toistuu vain 11 kertaa (35\%). Tutkan siirtymäsarja c-e-g toistuu 6 kertaa (19\%). Näiden summana on $25+12+35+19=91 \%$. Loput $9 \%$ jää sekuntisiirtymille $d-e-d$ ja $d$-c sekä kerran esiintyvälle pienelle terssille $d-f$. Siis peräti $37 \%$ siirtymistä tapahtuu kvintein ja oktaavein ja tämä piirre on jälleen yksi, jolla on vastaavuus aboriginaalien syntaksissa. Toisesta näkökulmasta voidaan sanoa, että näiden melodioiden syntaksi rakentuu vankasti perusparin varaan.

Neljäs erikoisuus on modaalisten ainesten sitominen toisiinsa asettamalla ne lomittain toistensa sisään. Tekniikka on tavallista solistin ja kuoron esitystavalle, mutta syntaksin rakennusvälineenä lomittaminen tässä määrin on epätavallista. Viidentenä erityispiirteenä on dominantin esiintyminen päätössävelenä. Symbolien c- $\Omega$ ja f- $\Omega$ määrä nuottiesimerkissä 5 kuvaa olennaista, eli arkkitoonikan keskeistä roolia laulun lopetussävelenä. Lisäksi on todettava, että sävelkulku $b^{1} 1_{-g} 1_{-} b_{-c}{ }^{2}$ on G-horisontissa olevan laulun aloituskuviona universaalisti epätavallinen, mutta ominainen ainakin keskijaavalaiselle syntaksille.

\section{Mietteitä}

Seuraavien rivien pontimena on kysymys: voidaanko keskijaavalaisen syntaksin erikoista luonnetta valaista tiedolla, joka nousee aivan toisenlaisista tutkimusaineistoista? Ajatuksia ei ole tarkoitettu todistamaan mitään, vaan herättämään uusia tutkimuskysymyksiä, joihin voidaan etsiä vastauksia musiikkianalyysin avulla. Tämä kirjoittajan peruslähtökohtana on kuitenkin se, ettei ole näkyvissä tietoja, joiden mukaan kaakkoisen Aasian nykyisten kulttuureiden muotoutumisessa olisi tapahtunut merkittäviä väestösiirtymiä ennen eikä jälkeen Lapita-kulttuurin ilmaantumista Indonesiaan. Tietenkin Manner-Aasian pronssikausi oli vaikuttanut teknologian alalla ja paljon myöhempi intialainen vaikutus uskonnon ja taiteen aloilla, mutta prosessit olivat akkulturaatiota. Täten Filippiinien, Indonesian ja Malakan niemen kulttuurien 
nykyisyys on ollut huomattavan pitkäaikaisten paikallisväestöjen ylläpitämien kulttuureiden hidasta muuntumista. Tämä on siis hypoteesin kaltaisena lähtökohtana.

Näyttää siltä, että keskeinen arkeologinen kulttuuri, joka aikanaan yhdisti geneettisesti Kaakkois-Aasian mantereen ja Jaavan mesoliittisen kulttuurin myöhempään neoliittiseen oli Hoabinhin kulttuuri, joka nimi tulee lähellä Hanoita olevan Hoa Binhin löytöpaikan mukaan. Tuo kulttuuri tunnettiin laajalti Kaakkois-Aasiassa, ja sen keskeisenä samankaltaisuutena oli yhtäläinen kiviteknologia. Sen edustajat olivat kalastelleita metsästäjäkeräilijöitä, jotka eivät vielä tuottaneet ruokaansa viljelemällä. Sen väestöt olivat omaksuneet saviastioiden valmistuksen n. $6000 \mathrm{eKr}$, mutta eivät alkaneet viljellä viljaa eivätkä kasvattaa juureksia ja hedelmiä ennen kuin 3. vuosituhannella eKr. On arveltu, että näitä neoliittisiä innovaatioita oli tuonut pohjoisen suunnalta saapunut väestö, jolla oli ollut mongoloidisia piirteitä. Elinkeinomuutokset johtivat ensimmäisten kiinteiden asutuskeskusten syntyyn. Hoabinhin kulttuuri on edelleen vajavaisesti tunnettu, mutta sen ainesten tiedetään levinneen Jaavalle, Borneoon ja Sumatralle jo ennen neoliittista aikaa. Toisaalta Kaakkois-Aasian saaret olivat asuttuja jo kauan ennen tuota kulttuuria. Australian alkuperäisväestön esivanhemmat olivat kauan sitten asuneet näillä nykyisin Indonesiaan kuuluvilla saarilla, vaikka todisteita nykyihmisen oleskelusta Keski-Jaavalla on vasta 45000 vuoden takaa ja Borneolla 40000 vuoden takaa. (Whitehouse \& Whitehouse 1973: 200-209; Hutterer 1998: 32-46.)

Hoabinhin kulttuuri ei ollut yhtenäinen makrokulttuuri, vaan monen erilaisen paikalliskulttuurin jakama yhdenmukainen kiviteknologia (aivan samaan tapaan kuin digi-teknologia yhdistää nykyisiä kulttuureita). Se kattoi Jangtze-joen alueen eteläisessä Kiinassa, Vietnamin, Thaimaan, Malesian ja Koillis-Sumatran aikavälillä 11 000-2 000 eKr., mutta oli omaksuttu Jaavan, Borneon ja Filippiinien väliseen saaristoon tai oli siirtynyt sinne väestömuuton mukana. Tämä arkeologinen tosiasia on mielenkiintoinen, sillä geeniperimään liittyvät tutkimukset osoittavat jaavalaisten olevan likeistä sukua Malesian malaijien ja Borneon Sarawakissa asuvien väestöjen kanssa. Heidän geneettisiä sukulaisiaan asuu myös Koillis-Borneolla sekä Itä- ja Keski-Intiassa, jossa asuvia kansoja kutsutaan yhteisnimellä Munda (WALS 2005: kieliryhmä 29.2). Kaikki mainitut kansat jakavat DNA:ssaan samat geneettiset tekijät, joiden vuoksi heitä kutsutaan Kaakkois-Aasian geneettiseksi B-ryppääksi. Yksityiskohta on merkittävä, sillä Kaakkois-Aasiassa on vain kolme geneettistä rypästä. Esimerkiksi sumatralaiset ja balilaiset Jaavan kummallakin puolella kuuluvat samaan 
A-ryppääseen kuin filippiiniläiset, thait ja Kamputsean khmerit. (Geneettiset tiedot ovat lähteestä Cavalli-Sforza ym. 1994: 207; 234-238.)

Arkeologien tapaan lingvisteilläkin tutkimus on paljolti kesken Kaakkois-Aasian valtaisan kielimäärän vuoksi. Alueella on kaksi suurta kieliperhettä. Austroaasialaisten kielten perhe on käytössä pääosin mantereella (ks. kartta 2). Siihen kuuluvia kieliä puhutaan eteläisessä Kiinassa, pohjoisessa Vietnamissa, Laosissa ja Thaimaassa eli muinaisen Hoabinhin teknologian alueella. Kaakkois-Aasian saaristossa puhuttujen kielten pääosa kuuluu taas Austronesian kieliperheeseen, jonka historia on ongelma (kuva 10). Siihen kuuluvia kieliä puhutaan Malesiasta ja Formosalta Tyynelle merelle aina Havaijia ja Pääsiäissaaria myöten. Austronesia tarkoittaa 'Eteläsaaristoa'. Kieliperheen kantakieltä oli puhuttu Formosalla jo noin 5 000-3 000 eKr. ja se lienee alkuaan irtautunut Kiinan mantereella olleesta austroaasialaisesta kieliperheestä (Comrie et al. 2003: 92-93). Vielä hiljan tutkijat olivat varsin erimielisiä austronesialaisten kielten kehityksestä ja niiden välisistä suhteista. Kuva 10 kuvaa alaperheiden välisiä suhteita laajan The World Atlas of Language Structures -teoksen pohjalta (WALS 2005). Siinä punaisella viivalla yhdistetyt alaperheet elävät Formosalla (Taiwanissa), vihreillä yhdistetyt levisivät Formosalta Malesiaan, Indonesiaan, Tyynelle valtamerelle - sekä toisaalla Itä-Afrikan Madagaskarille.

\subsection{Atajali Taiwan \\ 1.2. Keskinen malajo-polynesia Indonesia \\ AUSTRONESIA \\ 1.3. Itäinen malajo-polynesia Papua, Mikronesia \\ Polynesia \\ 1.4. Paiwani Taiwan \\ 1.5. Tsou Taiwan \\ 1.6. Läntinen malajo-polynesia Malesia, Indonesia, Filippiinit, Papua \\ -1.6.10. Sunda \\ Bali, Jaava, Sumatra, Malesia, \\ Thaimaa, Vietnam}

Kuva 10. Austronesialaisen eli Eteläsaariston kieliperheen jakautuminen alaperheisiin kieliatlaksen WALS 2005 mukaan. Mitä samankaltaisemmat kieliperheet ovat, sitä lähempänä ne ovat toisiaan. Artikkelin alussa mainittu sundan ryhmä on erikseen alhaalla. 


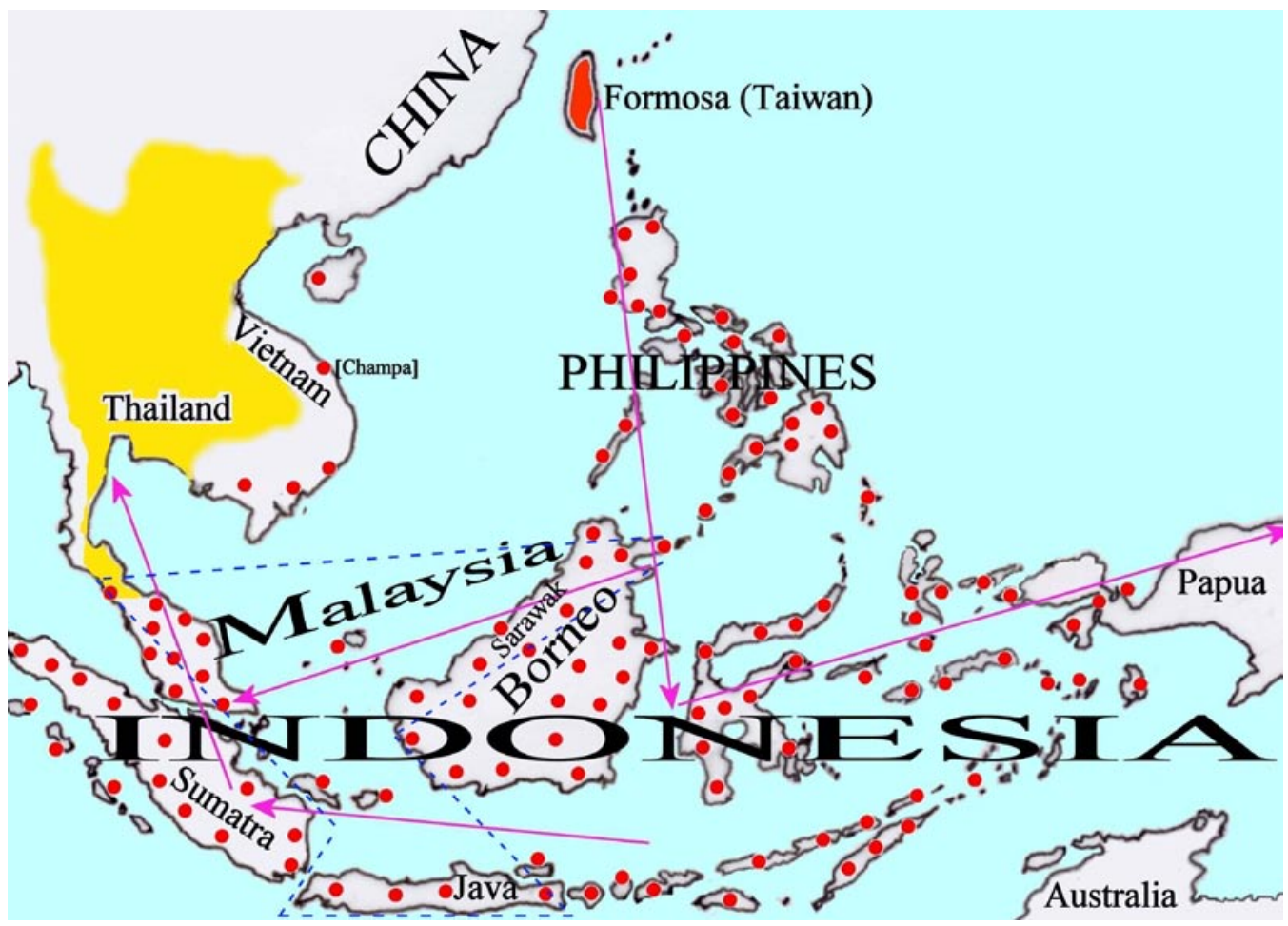

Kartta 2. Keltainen väri kattaa austroaasialaisen kieliperheen asuinalueen Benedictin (1975) mukaan. Austronesialaisten kielten kehitys käynnistyi noin 7000 vuotta sitten, kun väestöjä oli siirtynyt Kiinasta Formosan saarelle. Sieltä merenkulun mestareiksi oppineita saarelaisia alkoi muuttaa Filippiinien kautta etelään ja jakautua kohti itää (Pääsiäissaaret) ja länttä (Madagaskar). Kieliperheen puhunta-alue on merkitty punaisin pistein (Comrie ym. 2003). Sininen katkoviiva rajaa geneettisen B-ryppään elinalan.

Tutkijat ovat jo pitkään olleet yksimielisiä siitä, että malajo-polynesialaiset kielet alkoivat kehittyä omiin suuntiinsa väestöjen alettua muuttaa meriteitse Formosalta Filippiineille ja etelään 3 000-2 000 eKr. Muuttajat edustivat ns. Lapita-kulttuuria, jonka koristeellisissa saviesineissä on mm. polynesialaisen nykytaiteen keskeiset elementit. Prosessit ovat olleet monimutkaisia (Starosta 2002, 185-202), mitä kuva 10 osoittaa. Alaperheet ovat alakkain niin, että läntinen malaijo-polynesia eroaa eniten Formosan atajalista, joka taas on lähempänä Filippiineillä puhuttuja kieliä kuin samaisella Formosan saarella puhuttujen paiwanin ja tsoun alaperheiden kieliä. Havainto sopii arkeologien päätelmiin, sillä itäisen malajo-polynesialaisen kielen var- 
haisimmat edustajat saapuivat Borneolle jo noin 2500 eKr. (Hutterer 1998: 38) ja läntisen malajo-polynesialaisen kielen edustajat saapuivat paljon lännemmäksi eli Malesiaan jo noin $2000 \mathrm{eKr}$. (Roseman $\mathcal{E}$ Oesch 1998: 560).

Vaikka monet yksityiskohdat jäävät hämäriksi, mahdolliseksi käy sellaisen hypoteettisen hahmotelman muodostaminen, joka voi toimia musiikkianalyyttisen vertailun lähtökohtana. Jaava oli ollut asutettu kymmeniä tuhansia vuosia. Jossain vaiheessa Malakan niemen, Jaavan ja pohjoisen Borneon alueelle oli asettunut geneettiseen B-ryppääseen kuulunutta väestöä (kartta 2). Tämä väestö oli saapunut Jaavalle paljon austronesiaa puhuneita aiemmin. Jälkimmäisten lukumäärä ei voinut olla suuri, sillä he olivat liikkuneet venekuntina.

Austroaasialainen kieliperhe jaetaan kahteen alaryhmään, joista toisen, monkhmerin, levikki näkyy kartalla 2 keltaisena alueena. Onkin mahdollista, että geneettinen B-rypäs oli kehittynyt mantereella pienehkössä yhteisössä, joka oli puhunut varhaista austroaasialaista kieltä. Oletus pohjautuu sille tosiasialle, että kaikki saman ryppään läntisimmät edustajat, Intian mundat, puhuvat 10 eri kieltä (santalia, mundaria, soraa jne.), jotka muodostavat austroaasialaisten kielten toisen alaryhmän mon-khmer -kielten rinnalla. Täten myös Jaavalla oli puhuttu mundan sukukieltä ennen kuin väestö oli vaihtanut kielensä läntiseen malajopolynesiaan. En tiedä, milloin austronesian kieli saapui Jaavalle, mutta naapurissa olevalle Sumatralle se rantautui noin $500 \mathrm{eKr}$. joten sama olisi voinut tapahtua myös Jaavalla. Joka tapauksessa tiedetään, että Champan kuningaskunnan perustajien esi-isät saapuivat Vietnamin rannikolle (kartta 2) noin $200 \mathrm{jKr}$. Jaavalta ja he toivat mukanaan sekä hindulaisuuden että buddhalaisuuden (Nguyển 1998: 590).

Laajassa katsomossa Kaakkois-Aasian ihminen jakautuu kolmeen keskeiseen sukulinjaan, jotka ovat lähtöisin saman DNA:n jakaneesta alkupopulaatiosta. Niin ikään näyttää siltä, että austroaasialaiset ja austronesialaiset kielet olivat alkaneet haarautua n. 7.000 vuotta sitten kahteen eri suuntaan yhteisestä kielikannasta, jota Paul Benedict (1975) kutsui nimellä Austro-Thai (vertaa kuitenkin Thurgood 1994). Emme tiedä, mitä kaikkia kieliä Jaavalla oli puhuttu, mutta Papualla nykyisin puhutusta 700 kielestä joitakin oli saatettu puhua myös Jaavalla. Papualaisilla Itä-Ylämaan kielillä ja kanta-australialla on arveltu olevan geneettinen yhteys; olihan Australia ja Papua maayhteydessä kymmeniä vuosituhansia Sahulin kannaksen kautta, joka oli umpeutunut jääkauden jälkeen vasta noin 8.000 vuotta sitten (Foley 1986: 269273). Jos ihmiset astuivat nykyiseen Australiaan noin 50000 vuotta sitten, heidän esivanhempansa olivat kulkeneet $\mathrm{mm}$. Jaavan kautta samaa reittiä kuin papualais- 
ten esivanhemmat. Joidenkin syntaktisten piirteiden vuoksi Jaavalla on yhteyksiä australidien lauluun, joten on mahdollista, että Jaavalla asuneiden väestöjen musiikissa oli säilynyt hyvin arkaaisia piirteitä. Vaikka siis väestö oli vaihtanut kielensä austroaasiasta austronesiaaan, ja vaikka kielenvaihtoja oli saattanut olla useitakin, musiikille ominainen syntaksi oli säilynyt. Tämä ilmiö ei ole laisinkaan epätavallista kulttuurien historioissa: tunteiden kommunikaatiomekanismi saatetaan säilyttää kielenvaihdosta huolimatta. Aivan hiljan olen kohdannut tämän tutkiessasi Kuolan niemellä asuvien kildininsaamelaisten laulua.

Tässä sanottu johtaa moniin hypoteeseihin, joita on mahdollista testata. Ensinnäkin voidaan olettaa, että Formosalta muuttaneet austronesian kielen puhujat olivat olleet määrällisesti vähäisiä, mutta Lapita-kulttuurinsa vuoksi paikalliskulttuureita edistyneempiä. Tässä valossa voidaan olettaa, että jaavalaisen laulun syntaksista löytyy esiaustronesialaista substraattia, mutta miltä ajalta, sitä ei tiedetä. Oletukseni mukaan substraatti (jäänne alkuperäisväestön syntaksista) ei ole ainoastaan austronesian kielen omaksumista varhaisempi vaan myös geneettisen B-ryppään mukana saapunutta austroaasialaista vaihetta varhaisempi. Tämä tarkoittaa, että Jaavalla oli voinut säilyä lauluun liittyneitä syntaktisia aineksia, joilla on nimenomaan geneettinen yhteys australidien vastaaviin. Testi vaatii siis australidien, Papuan Itä-Ylämaan tiettyjen kansojen sekä Jaavan macapat-lauluston syntaktista vertailua. Oma aiheensa on selvitellä Formosan syntaktiset piirteet ja vertailla niitä macapatin piirteisiin. Ja aivan oma tehtävänsä on tutkia Malesian ja Borneon B-ryppään kansojen syntaksien suhteita jaavalaisiin tai vertailla Munda-kansojen syntaktisia piirteitä mon-khmer -kansojen piirteisiin.

\section{Kiitokset}

Olen kiitollinen professori Margaret Kartomille sekä Hidris Kartomille, jotka toimittivat käyttööni tässä analysoidut ja tutkijoille ennen tuntemattomat jaavalaiset laulut ja antoivat luvan niiden julkaisemiseen. Kiitos professori Gerald Langnerille luvasta käyttää hänen kuviaan sekä FT Martin Ebelingille luvasta julkaista kuvan 5 kuviot. Kiitän erityisesti professori Erkki Huovista, jonka kriittiset kannanotot pakottivat panostamaan tutkasävelteorian neurofysiologisten perusteiden selventämiseen. Ja kiitokset FT Reijo Lainelalle, joka alkuaan käynnisti tämän kirjoitusprosessin. Teksti on saatettu päätökseen osana Suomen Akatemian tutkimusprojektia 135480. 


\section{Lähteet}

\section{Käsikirjoitukset}

Kolme Margaret Kartomin nuotintamaa lastenlaulua Lagu dolanan pendhisil, Kupu kuwé (Kupu kuning) ja Gajah huhti- ja toukokuulta 2010, kirjoittajan hallussa.

\section{Kirjallisuus}

Benedict, Paul K. (1975) Austro-Thai. Language and Culture with a Glossary of Roots. New Haven: HRAF Press.

Cavalli-Sforza, Luca L.; Menozzi; Paolo; Piazza, Alberto (1994) The History and Geography of Human Genes. Princeton: Princeton University Press.

Comrie, Bernard; Stephen Mathews; Maria Polinsky (2003) The Atlas of Languages. The Origin and Development of Languages Throughout the World. London: Quarto Publishing.

Ebeling, Martin (2007) Verschmelzung und neuronale Autokorrelation als Grundlage einer Konsonanztheorie. Frankfurt: Peter Lang Verlag.

Ebeling, Martin (2008) "Neuronal periodicity detection as a basis for the perception of consonance: A mathematical model of tonal fusion". Journal of Acoustical Society of America. 124/4, ss. 2320-2329.

Ebeling, Martin (2009) "Calculating Tonal Fusion by the Generalized Coincidence Function". Mathematics and Computation in Music. Communication in computer and information science 37. Toim. Timour Klouche \& Thomas Noll. Ss. 140-155.

Foley, William A. (1986) The Papuan Languages of New Guinea. Cambridge: Cambridge University Press.

The Garland Encyclopedia of World Music. Volume 4: Southeast Asia. (1998) Toim. Terry E. Miller and Sean Williams. New York: Garland Publishing,

Huovinen, Erkki (2008) "Från proto-indoeuropeisk forntid till neurologi. En metodologisk översikt över det första decenniet av Timo Leisiös hexatonala teorier". Etnomusikologian vuosikirja 20, ss. 127-158.

Hutterer, Karl L. (1998) "Southeast Asia in Prehistory". The Garland Encyclopedia of World Music. Volume 4: Southeast Asia. Toim. Terry E. Miller \& Sean Williams. New York and London: Garland Publishing. Ss. 32-46.

Kartomi, Margaret J. (1973) Matjapat Songs in Central and West Java. Canberra: Australian National University Press.

Kartomi, Margaret J. (1980) "Childlikeness in Play Songs: A Case Study Among the Pitjantjara at Yalata, South Australia". Miscellanea Musicologica 11, ss. 172-214.

Kartomi, Margaret J. (1981) "Songs of Some Australian Aboriginal Children's Play Ceremonies". Studies in Music 15, ss. 1-35.

Kartomi, Margaret J. (1988) "Forty Thousand Years: Koori Music and Australian Music Education". Australian Journal of Music Education 1988/1, ss. 11-28.

Kartomi, Margaret J. (1990) "Musical Improvisations by Children at Play". The World of Music 33/3. ss. 53-65.

Kartomi, Margaret J (2001) "Play Songs by Children and their Educational Implications". Aboriginal History 23. Toim. Luise Hercus and Grace Koch. Canberra: Australian National University. Ss. $61-71$.

Lainela, Reijo (2010) Pathet. Musiikin symboliikkaa jaavalaisessa varjoteatterissa. Studia Musicologica Universitatis Helsingiensis 19. Helsinki: Helsingin yliopisto. 
Langner, Gerald (2007) "Jaksollisen signaalin aika-analyysi kuulojärjestelmässä: sävelkorkeuden, sointivärin ja harmonisuuden hermovasteet." Etnomusikologian vuosikirja 19. Ss. 213-235.

Langner, Gerald (2004) "Topographic Representation of Periodicity Information: The 2nd Neural Axis of the Auditory System". Plasticity of the Central Auditory System and Processing of Complex Acoustic Signals. Toim. J. Svka \& M.M. Merzenich. New York: Springer-Verlag. Ss. 19-33.

Langner, Gerald; Albert, Monika \& Briede, Thorsten (2002) "Temporal and spatial coding of periodicity information in the inferior colliculus of awake chinchilla (Chinchilla laniger)". Hearing Research 168, ss. 110-130.

Langner G.; Braun S.; Simonis C.; Benso C.; Cant N. (2006) "New evidence for a pitch helix in the ventral nucleus of the lateral lemniscus in the gerbil." Abstracts of the Association for Research in Otolaryngology 29, ss. 259-260.

Langner, G.; Sams, M.; Heil, P.; Schulze, H. (1997) "Frequency and Periodicity are represented in orthogonal maps in the human auditory cortex: evidence from magnetoencephalography". Journal of Comparative Physiology 181, ss. 651-663.

Langner, G. \& Schreiner, C. (1988) "Periodicity Coding in the Inferior Colliculus of the Cat: I Neuronal Mechanism." Journal of Neurophysiology 60, ss. 1799-1822.

Langner, G.; Simonis C.; Braun, S.; Ochse M. (2003) "Evidence for a Pitch Helix in the Ventral Nucleus of the Lateral Lemniscus in the Gerbil." Abstracts of the Association for Research in Otolaryngology 26, ss. 173.

Leisiö, Timo (2008) "Neurofysiologisesti perustellun siirtymäteorian käyttö melodia-analyysissä". Etnomusikologian vuosikirja 20, ss. 161-194.

Nguyển, Phong T. (1998) "The Lowland Chặm". The Garland Encyclopedia of World Music. Volume 4: Southeast Asia. Toim. Terry E. Miller \& Sean Williams. New York 1998: Garland Publishing. Ss. 590-591.

Rees, Adrian and Gerald Langner (2005) "Temporal Coding in the Auditory Midbrain." The Inferior Colliculus. Toim. Jeffery A. Winer \& Christoph E. Schreiner. New York: Springer Science. Ss. 346-376.

Roseman, Marina (1998) "The Indigenous Peoples [Orang Asli] of the Malay Peninsula". Perustuu osittain Hans Oeschin käsikirjoitukseen. The Garland Encyclopedia of World Music. Volume 4: Southeast Asia. Toim. Terry E. Miller \& Sean Williams. New York: Garland Publishing. Ss. 560-589.

Starosta, Stanley (2002) "The rise and fall and rise and fall of Proto Malayo-Polynesian". Collected papers on Southeast Asian and Pacific languages. Toim. Robert S Bauer. Pacific Linguistics 530. The Australian National University. Ss. 183-203.

Stumpf, Carl (1890) Tonpsychologie. Hilversum: Knuf.

Stumpf, Carl (1897) "Neueres über Tonverschmelzung". Zeitschift für Psychologie und Physiologie der Sinnesorgane Vol. 15, ss. 280-303.

Thurgood, Graham (1994) "Tai-Kadai and Austronesian: the Nature of the Relationship". Oceanic Linguistics 33, ss. 345-368.

WALS (2005) The World Atlas of Language Structures. Toim. Martin Haspelmath, Matthew S. Dryer, David Gil \& Bernard Comrie. Oxford: Oxford University Press.

Whitehouse, David \& Whitehouse, Ruth (1973) Archaeological Atlas of the World. London: Thames and Hudson. 